Cochrane Database of Systematic Reviews

\title{
Single dose oral ibuprofen plus codeine for acute postoperative pain in adults (Review)
}

Derry S, Karlin SM, Moore RA

Derry S, Karlin SM, Moore RA.

Single dose oral ibuprofen plus codeine for acute postoperative pain in adults.

Cochrane Database of Systematic Reviews 2015, Issue 2. Art. No.: CD010107.

DOI: 10.1002/14651858.CD010107.pub3.

www.cochranelibrary.com 
TABLE OF CONTENTS

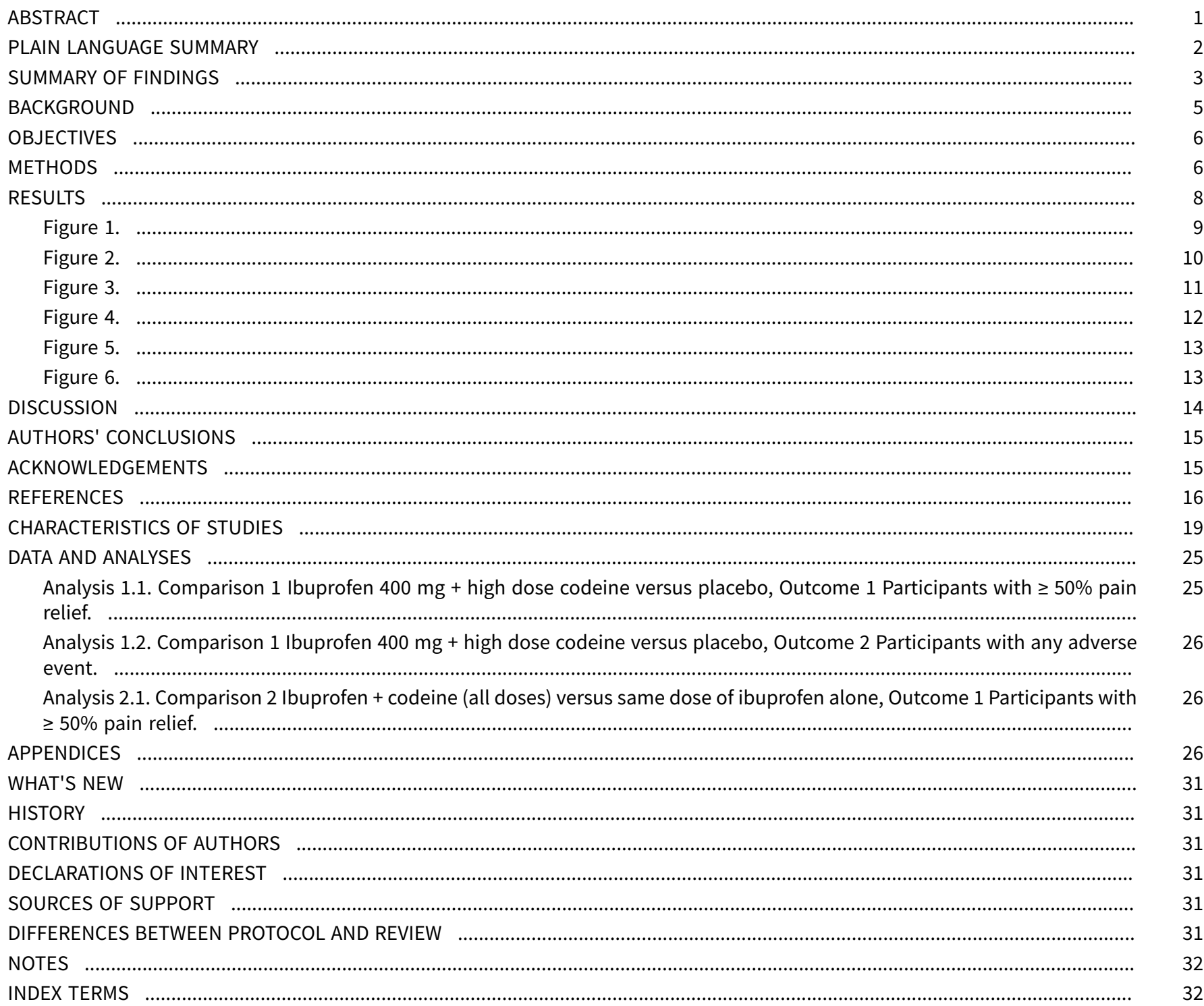


[Intervention Review]

\section{Single dose oral ibuprofen plus codeine for acute postoperative pain in adults}

Sheena Derry¹, Samuel M Karlin², R Andrew Moore 3

1Oxford, UK. 2Pain Research and Nuffield Department of Clinical Neurosciences, University of Oxford, Oxford, UK. ${ }^{3 P l y m o u t h, ~ U K ~}$

Contact: R Andrew Moore, Plymouth, UK. andrew.moore@omkltd.org.

Editorial group: Cochrane Pain, Palliative and Supportive Care Group.

Publication status and date: Stable (no update expected for reasons given in 'What's new'), published in Issue 5, 2019.

Citation: Derry S, Karlin SM, Moore RA. Single dose oral ibuprofen plus codeine for acute postoperative pain in adults. Cochrane Database of Systematic Reviews 2015, Issue 2. Art. No.: CD010107. DOI: 10.1002/14651858.CD010107.pub3.

Copyright @ 2019 The Cochrane Collaboration. Published by John Wiley \& Sons, Ltd.

\section{A B S T R A C T}

\section{Background}

This is an update of the original Cochrane review published in Issue 3, 2013. There is good evidence that combining two different analgesics in fixed doses in a single tablet can provide better pain relief in acute pain and headache than either drug alone, and that the drug-specific effects are essentially additive. This appears to be broadly true in postoperative pain and migraine headache across a range of different drug combinations and when tested in the same and different trials. Some combinations of ibuprofen and codeine are available without prescription (but usually only from a pharmacy) where the dose of codeine is lower, and with a prescription when the dose of codeine is higher.

Use of combination analgesics that contain codeine has been a source of some concern because of misuse from over-the-counter preparations.

\section{Objectives}

To assess the analgesic efficacy and adverse effects of a single oral dose of ibuprofen plus codeine for acute moderate-to-severe postoperative pain using methods that permit comparison with other analgesics evaluated in standardised trials using almost identical methods and outcomes.

\section{Search methods}

We searched the Cochrane Central Register of Controlled Trials (CENTRAL), MEDLINE, EMBASE, the Oxford Pain Relief Database, ClinicalTrials.gov, and the reference lists of articles. The date of the most recent search was 1 December 2014.

\section{Selection criteria}

Randomised, double-blind, placebo- or active-controlled clinical trials of single dose oral ibuprofen plus codeine for acute postoperative pain in adults.

\section{Data collection and analysis}

Two review authors independently considered trials for inclusion in the review, assessed risk of bias, and extracted data. We used the area under the pain relief versus time curve to derive the proportion of participants prescribed ibuprofen plus codeine, placebo, or the same dose of ibuprofen alone with at least $50 \%$ pain relief over six hours, using validated equations. We calculated the risk ratio (RR) and number needed to treat to benefit (NNT). We used information on the use of rescue medication to calculate the proportion of participants requiring rescue medication and the weighted mean of the median time to use. We also collected information on adverse effects. Analyses were planned for different doses of ibuprofen and codeine, but especially for codeine where we set criteria for low (<10 mg), medium (10 to $20 \mathrm{mg}$ ), and high (> $20 \mathrm{mg}$ ) doses. 


\section{Main results}

Since the last version of this review no new studies were found. Information was available from six studies with 1342 participants, using a variety of doses of ibuprofen and codeine. In four studies (443 participants) using ibuprofen $400 \mathrm{mg}$ plus codeine $25.6 \mathrm{mg}$ to $60 \mathrm{mg}$ (high dose codeine) $64 \%$ of participants had at least $50 \%$ maximum pain relief with the combination compared to $18 \%$ with placebo. The NNT was 2.2 (95\% confidence interval 1.8 to 2.6) (high quality evidence). In three studies (204 participants) ibuprofen plus codeine (any dose) was better than the same dose of ibuprofen (69\% versus 55\%) but the result was barely significant with a relative benefit of 1.3 (1.01 to 1.6) (moderate quality evidence). In two studies (159 participants) ibuprofen plus codeine appeared to be better than the same dose of codeine alone (69\% versus $33 \%$ ), but no analysis was done. There was no difference between the combination and placebo in the reporting of adverse events in these acute studies (moderate quality evidence).

\section{Authors' conclusions}

The combination of ibuprofen $400 \mathrm{mg}$ plus codeine $25.6 \mathrm{mg}$ to $60 \mathrm{mg}$ demonstrates good analgesic efficacy. Very limited data suggest that the combination is better than the same dose of either drug alone, and that similar numbers of people experience adverse events with the combination as with placebo.

\section{PLAIN LANGUAGE SUMMARY}

\section{Single dose oral ibuprofen plus codeine for acute postoperative pain in adults}

Acute pain is often felt soon after injury. Most people who have surgery have moderate or severe pain afterwards. Painkillers are tested in people with pain, often following the removal of wisdom teeth. This pain is usually treated with painkillers taken by mouth. Results can be applied to other forms of acute pain.

A series of Cochrane reviews looks at how good painkillers are. We know that in some circumstances combining different analgesics in the same tablet gives good pain relief to more people than either analgesic alone. This is particularly true using a combination of two painkillers that work by different mechanisms. This review looked at how good the combination of ibuprofen and codeine was in relieving moderate or severe pain after surgery, and is an update of an earlier review conducted in 2013.

For the original review, we found six studies with 1342 participants. For this update we searched up to December 2014, but found no additional studies. Ibuprofen $400 \mathrm{mg}$ plus high doses of codeine ( $25.6 \mathrm{mg}$ to $60 \mathrm{mg}$ ) provided effective pain relief for over 6 in 10 (64\%) of participants, compared with just under 2 in 10 (18\%) of participants with placebo (high quality evidence).

Adverse events occurred at similar rates with the ibuprofen/codeine combination and placebo in these single dose studies (moderate quality evidence). No serious adverse events or withdrawals due to adverse events occurred with the combination. It is important not to exceed the recommended dose for this combination painkiller. 
SUMMARY OF FINDINGS

\section{Summary of findings for the main comparison.}

Ibuprofen plus codeine compared with placebo for acute postoperative pain

Population: adults with moderate or severe acute postoperative pain

Settings: community or hospital

Intervention: ibuprofen $400 \mathrm{mg}+$ codeine $25.6 \mathrm{mg}$ to $60 \mathrm{mg}$

Comparison: placebo

\begin{tabular}{|c|c|c|c|c|c|c|}
\hline \multirow[t]{2}{*}{ Outcomes } & \multicolumn{2}{|c|}{ Probable outcome with } & \multirow{2}{*}{$\begin{array}{l}\text { Relative effect and NNT or } \\
\text { NNH } \\
(95 \% \mathrm{CI})\end{array}$} & \multirow{2}{*}{$\begin{array}{l}\text { Number of } \\
\text { studies, events }\end{array}$} & \multirow{2}{*}{$\begin{array}{l}\text { Quality of the } \\
\text { evidence } \\
\text { (GRADE) }\end{array}$} & \multirow[t]{2}{*}{ Comments } \\
\hline & Comparator & Intervention & & & & \\
\hline $\begin{array}{l}\text { At least } 50 \% \text { of maxi- } \\
\text { mum pain relief over } \\
4 \text { to } 6 \mathrm{~h}\end{array}$ & 180 in 1000 & 640 in 1000 & $\begin{array}{l}\text { RR } 4.1 \text { (2.8 to } 5.9) \\
\text { NNT } 2.2 \text { ( } 1.8 \text { to } 2.6 \text { ) }\end{array}$ & $\begin{array}{l}4 \text { studies } \\
443 \text { partici- } \\
\text { pants } \\
208 \text { events }\end{array}$ & High & $\begin{array}{l}\text { Adequate numbers of studies, par- } \\
\text { ticipants and events. Consistency } \\
\text { across studies }\end{array}$ \\
\hline $\begin{array}{l}\text { Participants with at } \\
\text { least } 1 \text { adverse event }\end{array}$ & 180 in 1000 & 280 in 1000 & $\begin{array}{l}\text { RR } 1.2 \text { (0.84 to } 1.7) \\
\text { NNH not calculated }\end{array}$ & $\begin{array}{l}4 \text { studies } \\
443 \text { partici- } \\
\text { pants } \\
109 \text { events }\end{array}$ & Moderate & $\begin{array}{l}\text { Adequate numbers of studies, par- } \\
\text { ticipants, but moderate number of } \\
\text { events. Consistency across studies. } \\
\text { Single dose studies may not reflect } \\
\text { clinical practice }\end{array}$ \\
\hline $\begin{array}{l}\text { Participants with } \\
\text { a serious adverse } \\
\text { event }\end{array}$ & $\begin{array}{l}\text { No serious ad- } \\
\text { verse events }\end{array}$ & Low & $\begin{array}{l}\text { Studies underpowered to de- } \\
\text { tect rare events }\end{array}$ & & & \\
\hline Deaths & No deaths & Low & $\begin{array}{l}\text { Studies underpowered to de- } \\
\text { tect rare events }\end{array}$ & & & \\
\hline
\end{tabular}

Cl: confidence interval; NNH: number needed to treat to harm; NNT: number needed to treat for benefit; RR: Risk Ratio

GRADE Working Group grades of evidence

High quality: Further research is very unlikely to change our confidence in the estimate of effect.

Moderate quality: Further research is likely to have an important impact on our confidence in the estimate of effect and may change the estimate.

Low quality: Further research is very likely to have an important impact on our confidence in the estimate of effect and is likely to change the estimate. 


\section{B A C K G R O U N D}

This is one of a series of reviews whose aim is to increase awareness of the range of analgesics that are potentially available, and present evidence for relative analgesic efficacy through indirect comparisons with placebo, in very similar trials performed in a standard manner, with very similar outcomes, and over the same duration. Such relative analgesic efficacy does not in itself determine choice of drug for any situation or patient, but guides policy-making at the local level. The series covers all analgesics licensed for acute postoperative pain in the UK, and dipyrone, which is commonly used in Spain, Portugal, and LatinAmerican countries. The results have been examined in an overview (Moore 2011a), and important individual reviews include ibuprofen (Derry 2009), codeine (Derry 2010), paracetamol (Toms 2008), and etoricoxib (Clarke 2012).

This is an update of a previously published review in The Cochrane Database of Systematic Reviews, on Single dose oral ibuprofen plus codeine for acute postoperative pain in adults (Derry 2013).

\section{Description of the condition}

Acute pain occurs as a result of tissue damage either accidentally due to an injury or as a result of surgery. Acute postoperative pain is a manifestation of inflammation due to tissue injury or nerve injury, or both. The management of postoperative pain and inflammation is a critical component of patient care.

\section{Description of the intervention}

\section{Acute pain trials}

Single dose analgesic trials in acute pain are commonly short in duration, rarely lasting longer than 12 hours. The numbers of participants are small, allowing no reliable conclusions to be drawn about safety. To show that the analgesic is working, it is necessary to use placebo (McQuay 2005). There are clear ethical considerations in doing this. These ethical considerations are answered by using acute pain situations where the pain is expected to go away, and by providing additional analgesia, commonly called rescue analgesia, if the pain has not diminished after about an hour. This is reasonable, because not all participants given an analgesic will have significant pain relief. Approximately $18 \%$ of participants given placebo will have significant pain relief (Moore 2006), and up to $50 \%$ may have inadequate analgesia with active medicines (Moore 2013). The use of additional or rescue analgesia is hence important for all participants in these trials.

Clinical trials measuring the efficacy of analgesics in acute pain have been standardised over many years. Trials have to be randomised and double-blind. Typically, in the first few hours or days after an operation, patients develop pain that is moderate to severe in intensity, and will then be given the test analgesic or placebo. Pain is measured immediately before the intervention using standard pain intensity scales, and then using pain intensity and pain relief scales over the following four to six hours for shorteracting drugs, and up to 12 or 24 hours for longer-acting drugs. Pain relief of half the maximum possible pain relief or better (at least $50 \%$ pain relief) is typically regarded as a clinically useful outcome. For patients given rescue medication it is usual for no additional pain measurements to be made, and for all subsequent measures to be recorded as initial pain intensity or baseline (zero) pain relief (baseline observation carried forward). This process ensures that analgesia from the rescue medication is not wrongly ascribed to the test intervention. In some trials the last observation is carried forward, which gives an inflated response for the test intervention compared to placebo, but the effect has been shown to be negligible over four to six hours (Moore 2005). Trial participants usually remain in the hospital or clinic for at least the first six hours following the intervention, with measurements supervised, although they may then be allowed home to make their own measurements in trials of longer duration.

Knowing the relative efficacy of different analgesic drugs at various doses can be helpful.

\section{Ibuprofen}

Ibuprofen is a non-steroidal anti-inflammatory drug (NSAID). It was developed in the 1960s and is used extensively throughout the world for relief of pain and inflammation in both acute and chronic conditions. It is available over the counter in most countries, usually as $200 \mathrm{mg}$ tablets, with $1200 \mathrm{mg}$ as the recommended maximum daily dose for adults. Under medical supervision, up to $3200 \mathrm{mg}$ daily may be taken, divided into three doses. Soluble salts of ibuprofen have better efficacy (Derry 2009).

A major concern regarding the use of conventional NSAIDs postoperatively is the possibility of bleeding from both the operative site (because of the inhibition of platelet aggregation) (Forrest 2002), and from the upper gastrointestinal tract (especially in patients stressed by surgery, the elderly, frail, or dehydrated). Other potentially serious adverse events include acute liver injury, acute renal injury, heart failure, and adverse reproductive outcomes (Hernandez-Diaz 2001). However, such complications are more likely to occur with chronic use and NSAIDs generally present fewer risks if used in the short term, as in the treatment of postoperative pain (Rapoport 1999).

\section{Codeine}

Codeine is an opioid. People's response to opioids varies considerably, so that dose frequently needs to be adjusted individually. The usual dose by mouth for adults is $30 \mathrm{mg}$ to 60 $\mathrm{mg}$ every four hours, to a maximum of $240 \mathrm{mg}$ daily. As with other opioids, repeated administration of codeine in the absence of pain can cause dependence and tolerance, but long-term use for pain relief, or use of high doses, tends to be limited by adverse effects, in particular constipation and drowsiness. In severe or persistent pain, or both, for which large amounts of codeine are required, smaller doses of stronger opioids are thought to be better tolerated. Respiratory depression is dose-related and may have serious consequences in people without previous experience of opioid use, those who are "extensive metabolizers" (able to convert more of the codeine to morphine than is usual), and the elderly in whom reduced renal function leads to accumulation of active metabolites. Misuse of codeine combination products has resulted in serious morbidity from gastrointestinal bleeding and/or dependence associated with exceptionally high doses (mean daily doses of 435 to $602 \mathrm{mg}$ of codeine phosphate and 6800 to $9400 \mathrm{mg}$ ibuprofen) (Frei 2010). People can become addicted to the codeine and can then experience toxicity from the ibuprofen component of the combination analgesic (Pilgrim 2013). 


\section{How the intervention might work}

Clinicians prescribe NSAIDs on a routine basis for a range of causes of mild-to-moderate pain. NSAIDs are the most commonly prescribed analgesic medications worldwide, and their efficacy for treating acute pain has been well demonstrated (Moore 2003). They reversibly inhibit cyclooxygenase (prostaglandin endoperoxide synthase), the enzyme mediating production of prostaglandins and thromboxane A2 (FitzGerald 2001). Prostaglandins mediate a variety of physiological functions such as maintenance of the gastric mucosal barrier, regulation of renal blood flow, and regulation of endothelial tone. They also play an important role in inflammatory and nociceptive processes. Ibuprofen, like most NSAIDs, causes reversible inhibition of the cyclooxygenases, which interferes with thromboxane and prostaglandin synthesis, and increases production of anti-inflammatory lipoxins.

Codeine is an opioid. Its analgesic effects are attributed to its metabolism in the liver to the active compounds morphine and morphine-6-glucuronide. Normally, between $5 \%$ and $10 \%$ of codeine is converted to morphine, and a dose of about $30 \mathrm{mg}$ codeine phosphate is considered equivalent to $3 \mathrm{mg}$ morphine. The capacity to metabolise codeine to its active metabolites varies between individuals, however, with up to $10 \%$ of Caucasians, $2 \%$ of Asians and $1 \%$ of Arabs being "poor metabolizers" (able to convert less of the codeine to morphine than is usual) (Cascarbi 2003). In these individuals codeine is a relatively ineffective analgesic. A few individuals are "extensive metabolizers", putting them at increased risk of toxicity from standard doses. Various medications interfere with the enzymes that catalyse the metabolism of codeine, increasing or decreasing the extent of conversion and hence the analgesic effect. For example, the selective serotonin reuptake inhibitors fluoxetine and paroxetine reduce conversion, while rifampicin and dexamethasone increase conversion.

\section{Combination analgesics}

We now have convincing evidence that combining two analgesics can provide additional levels of analgesia in acute pain and headache (Moore 2011b; Moore 2012), and that the drugspecific effects are essentially additive (Moore 2012). The efficacy of combination analgesics in postoperative pain and migraine headache is essentially equivalent to the sum of the efficacies of the individual analgesic components across a range of different drug combinations, and when tested in the same and different trials (Moore 2012). There is no convincing evidence for combination analgesics in chronic pain, however (Chaparro 2012).

\section{Why it is important to do this review}

Ibuprofen is a widely available and inexpensive NSAID with proven efficacy in relief of acute postoperative pain (Derry 2009). Codeine is also widely available and relatively inexpensive, and although it has not shown good efficacy on its own in single doses in acute postoperative pain (Derry 2010), in combination it has been shown to significantly enhance the efficacy of paracetamol (Toms 2009), and other drugs (Moore 2012). The two drugs are used in combination in clinical practice and are available as a fixeddose combination tablet over-the-counter in some countries (in the UK there are no combination analgesic preparations that contain a higher dose of codeine than $12.8 \mathrm{mg}$ codeine phosphate (equivalent to $10 \mathrm{mg}$ codeine base per tablet) available without prescription). It is important to know how this combination compares with other analgesics when assessed in the same way (Moore 2011a).

\section{O B JECTIVES}

To assess the analgesic efficacy and adverse effects of a single oral dose of ibuprofen plus codeine for acute moderate-to-severe postoperative pain using methods that permit comparison with other analgesics evaluated in standardised trials using almost identical methods and outcomes.

\section{METHODS}

\section{Criteria for considering studies for this review}

\section{Types of studies}

We included double-blind studies with at least 10 participants randomly allocated to each treatment group of single dose oral ibuprofen plus codeine compared with placebo, or the same dose of ibuprofen alone, for the treatment of moderate to severe postoperative pain in adults. We included multiple dose studies if appropriate data from the first dose were available, and crossover studies provided that data from the first arm were presented separately.

We excluded the following:

- review articles, case reports, and clinical observations;

- studies of experimental pain;

- studies where pain relief was assessed only by clinicians, nurses, or carers (not patient-reported);

- studies of less than four hours' duration or studies that fail to present data over four to six hours post dose.

For postpartum pain, we included studies if the pain investigated was due to episiotomy or Caesarean section irrespective of the presence of uterine cramps; we excluded studies investigating pain due to uterine cramps alone.

\section{Types of participants}

We included studies of adult participants (> 15 years) with established postoperative pain of moderate-to-severe intensity following day or in-patient surgery. For studies using a visual analogue scale (VAS), we considered that pain intensity of greater than $30 \mathrm{~mm}$ equates to pain of at least moderate intensity (Collins 1997).

\section{Types of interventions}

Ibuprofen plus codeine, administered as a single oral dose, compared with matched placebo or the same dose of ibuprofen alone for postoperative pain. The ibuprofen and codeine could be administered as separate tablets taken together, or in a combined tablet. We included all dose combinations.

\section{Types of outcome measures}

We collected the following data where available.

- Participant characteristics.

- Patient reported pain at baseline (physician, nurse, or carerreported pain was not be included in the analysis). 
- Patient reported pain relief expressed at least hourly over four to six hours using validated pain scales (pain intensity or pain relief in the form of VAS or categorical scales, or both).

- Patient global assessment of efficacy (PGE), using a standard categorical scale.

- Time to use of rescue medication.

- Number of participants using rescue medication.

- Number of participants with one or more adverse events.

- Number of participants with serious adverse events.

- Number of withdrawals (all-cause, adverse events).

\section{Primary outcomes}

Participants achieving at least $50 \%$ pain relief over four to six hours.

\section{Secondary outcomes}

1. Median (or mean) time to use of rescue medication.

2. Participants using rescue medication.

3. Participants with: any adverse event; any serious adverse event (as reported in the study); withdrawal due to an adverse event.

4. Other withdrawals: withdrawals for reasons other than lack of efficacy (participants using rescue medication).

\section{Search methods for identification of studies}

\section{Electronic searches}

We searched the following databases.

- The Cochrane Central Register of Controlled Trials (CENTRAL) in The Cochrane Library (to 30 September 2012 for the original review and from 2012 to 1 December 2014 for the update).

- MEDLINE (via Ovid) (to 30 September 2012 for the original review and from 2012 to 1 December 2014 for the update).

- EMBASE (via Ovid) (to 30 September 2012 for the original review and from 2012 to 1 December 2014 for the update).

- The Oxford Pain Relief Database (Jadad 1996a).

See Appendix 1 for the MEDLINE search strategy, Appendix 2 for the EMBASE search strategy, and Appendix 3 for the CENTRAL search strategy. We did not limit the searches by language.

\section{Searching other resources}

We searched for additional studies in reference lists of retrieved articles and reviews, and on the clinicaltrials.gov web site. The manufacturers of the combination formulation (Reckitt Benckiser) had already been asked for information on published and unpublished studies, but did not know of any additional studies.

\section{Data collection and analysis}

\section{Selection of studies}

Two review authors independently assessed the search results and agreed on the studies to be included in the review. Disagreements would have been resolved by consensus or referral to a third review author, but this was not necessary.

\section{Data extraction and management}

Two review authors extracted data and recorded them on a standard data extraction form. One review author entered data suitable for pooling into Review Manager (RevMan 2011).

\section{Assessment of risk of bias in included studies}

We used the Oxford Quality Score as the basis for study inclusion, limiting inclusion to studies that were randomised and doubleblind as a minimum (Jadad 1996b).

We also completed a 'Risk of bias' table using methods adapted from those described by the Cochrane Pregnancy and Childbirth Group. Two authors independently assessed risk of bias for each study using the criteria outlined in the Cochrane Handbook for Systematic Reviews of Interventions, resolving any disagreements by discussion (Higgins 2011). The following were assessed for each study.

1. Random sequence generation (checking for possible selection bias). We assessed the method used to generate the allocation sequence as: low risk of bias (any truly random process: random number table; computer random number generator); unclear risk of bias (method used to generate sequence not clearly stated). We excluded studies using a non-random process, which were therefore at high risk of bias (odd or even date of birth; hospital or clinic record number).

2. Allocation concealment (checking for possible selection bias). The method used to conceal allocation to interventions before assignment determines whether the intervention allocation could have been foreseen in advance of, or during recruitment, or changed after assignment. We assessed the methods as: low risk of bias (telephone or central randomisation; consecutively numbered sealed opaque envelopes); unclear risk of bias (method not clearly stated). We excluded studies that did not conceal allocation, which were therefore at high risk of bias (open list).

3. Blinding of outcome assessment (checking for possible detection bias). We assessed the methods used to blind study participants and outcome assessors from knowledge of which intervention a participant received. We assessed the methods as: low risk of bias (study stated that it was blinded and described the method used to achieve blinding: identical tablets; matched in appearance and smell); unclear risk of bias (study stated that it was blinded but did not provide an adequate description of how blinding was achieved). We excluded studies that were not double-blind and therefore at high risk of bias.

4. Size (checking for possible biases confounded by small size). Small studies have been shown to overestimate treatment effects, probably because the conduct of small studies is more likely to be less rigorous, allowing critical criteria to be compromised (Deschartres 2013; Nüesch 2010). Studies were considered to be at low risk of bias if they had 200 participants or more, at unclear risk if they had 50 to 200 participants, and at high risk if they had fewer than 50 participants.

\section{Measures of treatment effect}

We used risk ratio (or relative risk, RR) to establish statistical difference, and numbers needed to treat to benefit (NNT) and pooled percentages as absolute measures of benefit or harm.

We use the following terms to describe adverse outcomes in terms of harm or prevention of harm.

- When significantly fewer adverse outcomes occur with treatment than with control (placebo or active) we use the term the number needed to treat to prevent one event (NNTp). 
- When significantly more adverse outcomes occur with treatment compared with control (placebo or active) we use the term the number needed to harm or cause one event (NNH).

\section{Unit of analysis issues}

We accepted only randomisation to the individual participant.

\section{Dealing with missing data}

The only likely issue with missing data in these studies was from imputation using last observation carried forward when a participant requested rescue medication. We have previously shown that this does not affect results for up to six hours after taking study medication (Moore 2005).

\section{Assessment of heterogeneity}

We examined heterogeneity visually using L'Abbé plots (L'Abbé 1987), a visual method for assessing differences in results of individual studies.

\section{Data synthesis}

For efficacy analyses we used the number of participants in each treatment group who were randomised, received medication, and provided at least one post-baseline assessment. For safety analyses we used the number of participants randomised to each treatment group who took the study medication. Results for different doses were analysed separately.

For each study we converted the mean total pain relief (TOTPAR), summed pain intensity difference (SPID), VAS TOTPAR, or VAS SPID (see Appendix 4) values for the active and placebo groups to \%maxTOTPAR or \%maxSPID by division into the calculated maximum value (Cooper 1991). We then calculated the proportion of participants in each treatment group who achieved at least 50\%maxTOTPAR using verified equations (Moore 1996; Moore 1997a; Moore 1997b). We converted these proportions into the number of participants achieving at least 50\%maxTOTPAR by multiplying by the total number of participants in the treatment group. We used this information on the number of participants with at least 50\%maxTOTPAR for active and placebo groups to calculate risk ratio and NNT.

We accepted the following pain measures for the calculation of TOTPAR or SPID (in order of priority; (see Appendix 4).

- Five-point categorical pain relief (PR) scales with comparable wording to 'none, slight, moderate, good or complete'.

- Four-point categorical pain intensity (PI) scales with comparable wording to 'none, mild, moderate, severe'.

- VAS for pain relief.

- VAS for pain intensity.

If none of these measures was available, we used the number of participants reporting 'very good or excellent' on a five-point categorical global scale with the wording 'poor, fair, good, very good, excellent' for the number of participants achieving at least $50 \%$ pain relief (Collins 2001).

For each treatment group we extracted the number of participants reporting treatment-emergent adverse effects, and calculated relative benefit and risk estimates with 95\% confidence intervals (Cl) using a fixed-effect model (Morris 1995). We calculated NNT and NNH with $95 \% \mathrm{Cls}$ using the pooled number of events using the method of Cook and Sackett (Cook 1995). We assumed a statistically significant difference from control when the $95 \% \mathrm{Cl}$ of the RR did not include the number one.

\section{Subgroup analysis and investigation of heterogeneity}

We planned subgroup analyses to determine the effect of dose and presenting condition (pain model: dental versus other postoperative pain (Barden 2004)). In particular, there are issues around the dose of codeine; if there were sufficient data we intended to analyse the findings according to low $(<10 \mathrm{mg}$ ), medium (10 mg to $20 \mathrm{mg}$ ), and high (> $20 \mathrm{mg}$ ) doses of codeine. A minimum of two studies and 200 participants had to be available in any subgroup or sensitivity analysis (Moore 1998), which was restricted to the primary outcome (at least $50 \%$ pain relief over four to six hours) and the dose with the greatest amount of data. We would determine significant differences between NNT, NNTp, or NNH for different groups in subgroup and sensitivity analyses using the $z$ test (Tramèr 1997).

\section{Sensitivity analysis}

We planned sensitivity analyses for quality score (two versus three or more) and trial size (39 or fewer versus 40 or more per treatment arm).

\section{RES U L T S}

\section{Description of studies}

\section{Included studies}

We identified six studies, with 1342 participants, that fulfilled the inclusion criteria (Cooper 1982; Daniels 2011; Frame 1986; McQuay 1989; Petersen 1993; Sunshine 1987). Details of individual studies are in the Characteristics of included studies table.

All of the included studies recruited participants aged 16 years or older (mean ages ranged from 20 to 26 years) and the majority of participants were female (50\% to $100 \%$ in individual studies). One study, with 195 participants, included women who had undergone episiotomy, Caesarian section, or other gynaecological surgery (Sunshine 1987), and the remaining five included men and women who had undergone surgical extraction of one to four impacted third molars, at least one of which had to be mandibular. Participants were required to be in good general health, and were excluded if they had a history of gastrointestinal disturbance, renal or hepatic disease, psychiatric disorder, or required medication that might interfere with the study results. In all studies participants took their medication when baseline pain reached moderate or severe intensity. Pain intensity and pain relief were measured at set time intervals after dosing on standard 4- and 5-point scales respectively, or $100 \mathrm{~mm}$ VAS, or both, with the exception of Frame 1986, in which a non-standard scale was used for pain intensity. Three studies also carried out patient global evaluation of treatment at the end of treatment using a standard 5-point scale (Cooper 1982; Daniels 2011; McQuay 1989).

Four studies used only a single dose (Cooper 1982; Daniels 2011; Frame 1986; Sunshine 1987), and two used multiple doses, but provided results for the first dose for some outcomes (McQuay 1989; Petersen 1993). 
Studies used placebo or active comparators, or both. The following treatments were administered.

- Ibuprofen $200 \mathrm{mg}+$ codeine $15 \mathrm{mg}$ (Frame 1986), $\mathrm{n}=32$.

- Ibuprofen $200 \mathrm{mg}+$ codeine $30 \mathrm{mg}$ (Sunshine 1987), $\mathrm{n}=40$.

- Ibuprofen $400 \mathrm{mg}+$ codeine $20 \mathrm{mg}$ (McQuay 1989), $\mathrm{n}=24$.

- Ibuprofen 400 mg + codeine 26.5 or 30 mg (Daniels 2011; Frame 1986), $n=195$.

- Ibuprofen 400 mg + codeine 60 mg (Cooper 1982; Petersen 1993; Sunshine 1987), $\mathrm{n}=110$.

- Ibuprofen $800 \mathrm{mg}+$ codeine $60 \mathrm{mg}$ (Frame 1986), $\mathrm{n}=26$.

- Ibuprofen 400 mg (Cooper 1982; McQuay 1989; Petersen 1993; Sunshine 1987), $n=132$.

- Codeine 60 mg (Cooper 1982; Sunshine 1987), $\mathrm{n}=78$.

- Placebo (Cooper 1982; Daniels 2011; Frame 1986; Sunshine 1987), $\mathrm{n}=167$.

- Aspirin 600 or 650 mg (Cooper 1982; Frame 1986), $\mathrm{n}=63$.

- Aspirin $650 \mathrm{mg}$ + codeine $60 \mathrm{mg}$ (Cooper 1982), $\mathrm{n}=45$.

- Paracetamol $1000 \mathrm{mg}+$ codeine $60 \mathrm{mg}$ (Daniels 2011), $\mathrm{n}=113$.

- Ibuprofen $200 \mathrm{mg}$ + paracetamol $500 \mathrm{mg}$ (Daniels 2011), $\mathrm{n}=173$.
- Ibuprofen $400 \mathrm{mg}$ + paracetamol $1000 \mathrm{mg}$ (Daniels 2011), $\mathrm{n}=168$.

Using our predefined categories, no treatment arms used low dose codeine $(<10 \mathrm{mg}$ ), two used medium dose codeine ( $10 \mathrm{mg}$ to 20 mg; Frame 1986; McQuay 1989), and the remainder used high dose codeine (> $20 \mathrm{mg}$; range $26.5 \mathrm{mg}$ to $60 \mathrm{mg}$ ).

\section{Excluded studies}

We excluded eight studies after reading the full papers (Carlos 1989; Cater 1985; Giles 1985; Giles 1986; Hellman 1992; McQuay 1992; Norman 1985; Walton 1990). Details of the reasons for exclusion are in the Characteristics of excluded studies table.

\section{Risk of bias in included studies}

All included studies were randomised and double-blind; one study scored 5/5 on the Oxford Quality Score (Daniels 2011), and the remaining five scored $4 / 5$ due to failure to report the method used to generate the randomisation schedule. It is likely that this was a failure of reporting rather than a flaw in the methods.

We assessed the risk of bias using the 'Risk of bias' tool (Figure 1; Figure 2). Details for each study are in the Characteristics of included studies table.

\section{Figure 1. 'Risk of bias' graph: review authors' judgements about each risk of bias item presented as percentages} across all included studies.

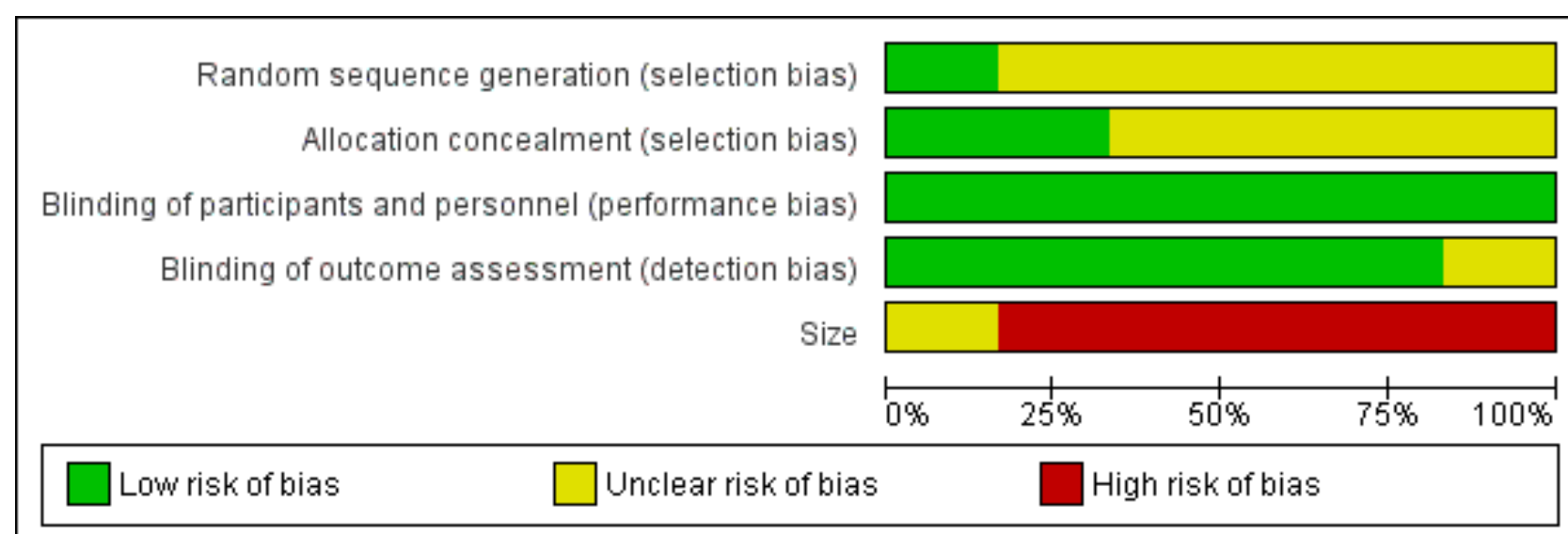


Figure 2. Risk of bias summary: review authors' judgements about each risk of bias item for each included study.

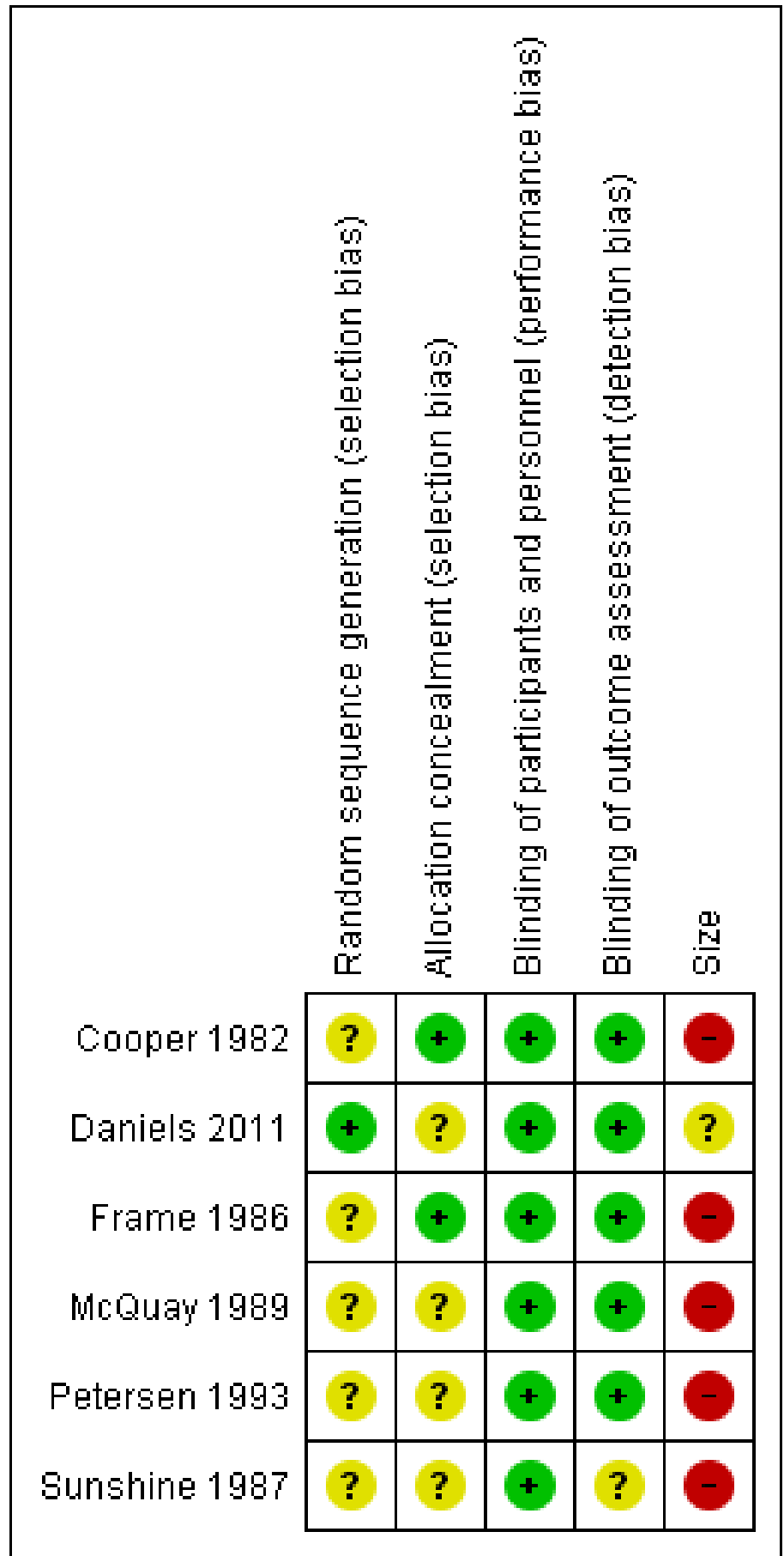

\section{Allocation}

All studies reported that they were randomised, but only one properly described the method used to generate the schedule. Two studies described the methods used to conceal the random allocation (Cooper 1982; Frame 1986), while in the other studies this was not described.

\section{Blinding}

All studies were double-blind and adequately described how this was achieved.

\section{Other potential sources of bias}

Treatment group size was an issue. None of the treatment groups in this review was large enough to be confident that bias would be avoided; five of the six studies had treatment group sizes that put them at high risk of bias.

\section{Effects of interventions}

See: Summary of findings for the main comparison 
The small numbers of participants in most of these treatment groups meant that analysis was severely limited. Results for individual studies are provided in Appendix 5 (analgesia and use of rescue medication) and Appendix 6 (adverse events and withdrawals).

\section{Participants with at least $50 \%$ pain relief}

One study with 60 participants did not report data in a way that could be used to calculate the primary outcome of this review, (Petersen 1993). It reported that the mean percentage pain reduction over 10 hours following the first dose (using last observation carried forward for participants who remedicated) was $63 \%$ (standard deviation (SD) 25) for the ibuprofen $400 \mathrm{mg}+$ codeine $60 \mathrm{mg}$ group, and 50\% (SD 31) for the ibuprofen $400 \mathrm{mg}$ group ( $P=0.12$ ), but last observation carried forward is known to be an inappropriate method in acute pain studies in studies longer than six hours (Moore 2005).

\section{Ibuprofen 200 mg + codeine versus placebo}

One study included a comparison of ibuprofen $200 \mathrm{mg}+$ codeine 15 $\mathrm{mg}$ (medium dose) with placebo; $18 / 32$ participants experienced at least $50 \%$ pain relief with the combination, and $10 / 26$ with placebo (Frame 1986).

One study included a comparison of ibuprofen $200 \mathrm{mg}+$ codeine $30 \mathrm{mg}$ (high dose) with placebo; 23/40 participants experienced at least $50 \%$ pain relief with the combination, and $13 / 40$ with placebo (Sunshine 1987).

\section{Ibuprofen 400 mg + codeine versus placebo}

Four studies (443 participants) included comparisons of ibuprofen $400 \mathrm{mg}$ + codeine $25.6 \mathrm{mg}$ to $60 \mathrm{mg}$ (high dose) with placebo (Cooper 1982; Daniels 2011; Frame 1986; Sunshine 1987).

- The proportion of participants with at least $50 \%$ pain relief with ibuprofen + codeine was $64 \%$ (178/276, range $62 \%$ to $73 \%$ ).

- The proportion of participants with at least $50 \%$ pain relief with placebo was $18 \%$ (30/167, range $4 \%$ to $38 \%)$.

- The relative benefit of treatment compared with placebo was 4.1 $(95 \% \mathrm{Cl} 2.8$ to 5.9 ); the NNT was 2.2 (1.8 to 2.6). (Analysis 1.1; Figure 3).

Figure 3. Forest plot of comparison: ibuprofen $400 \mathrm{mg}$ + high dose codeine (ibu/cod) versus placebo, outcome: 2.1 Participants with at least $50 \%$ pain relief.

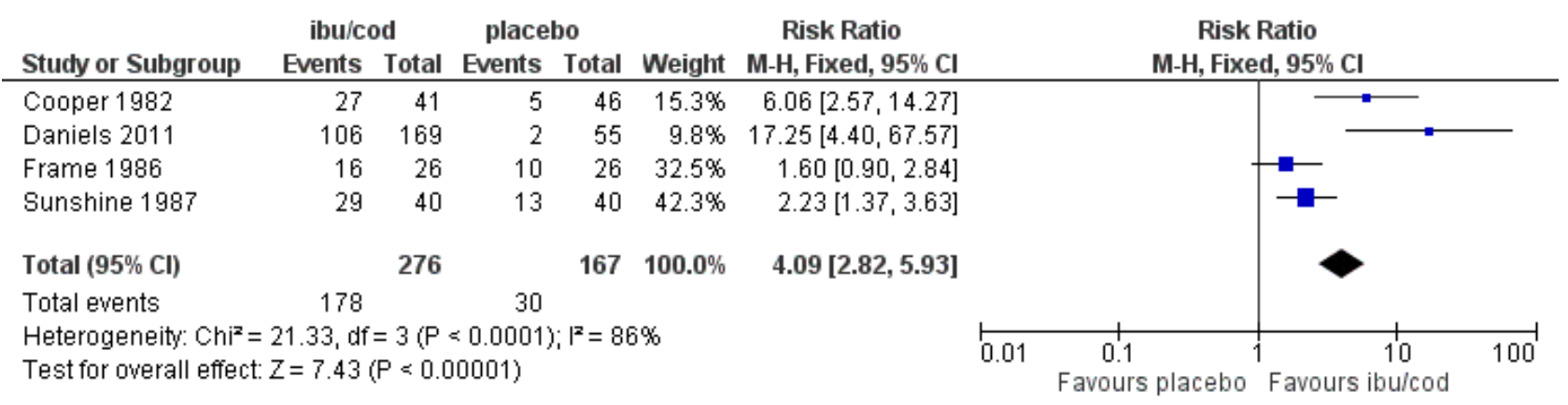

\section{Ibuprofen $800 \mathrm{mg}+$ codeine versus placebo}

One study included a comparison of ibuprofen $800 \mathrm{mg}+$ codeine $60 \mathrm{mg}$ (high dose) with placebo; $18 / 26$ participants experienced at least $50 \%$ pain relief with the combination, and $10 / 26$ with placebo Figure 4 shows the distribution of results for all combinations of ibuprofen and codeine compared with placebo; the dose of codeine made little obvious difference to the proportion of patients benefiting with the combination. 
Figure 4. Studies comparing ibuprofen plus codeine with placebo, with the outcome of at least $50 \%$ maximum pain relief over 4 to 6 hours. Colour code: white - ibuprofen $200 \mathrm{mg}+$ codeine $15 \mathrm{mg}$; yellow - ibuprofen $200 \mathrm{mg}+$ codeine $30 \mathrm{mg}$; light pink - ibuprofen $400 \mathrm{mg}+$ codeine $25.6 \mathrm{mg}$; medium pink - ibuprofen $400 \mathrm{mg}+$ codeine $30 \mathrm{mg}$; red ibuprofen $400 \mathrm{mg}+$ codeine $60 \mathrm{mg}$; blue - ibuprofen $800 \mathrm{mg}+$ codeine $60 \mathrm{mg}$.

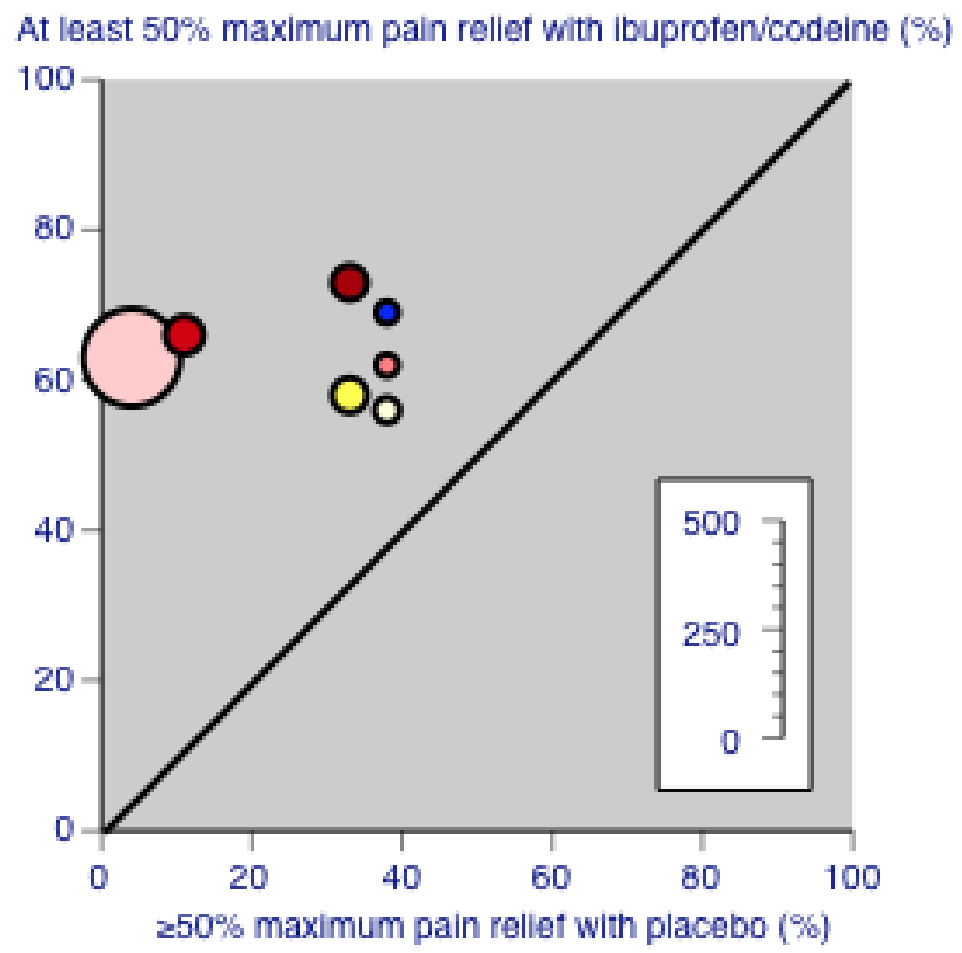

\section{Ibuprofen $400 \mathrm{mg}+$ codeine versus same dose of ibuprofen alone}

One study compared ibuprofen $400 \mathrm{mg}+$ codeine $20 \mathrm{mg}$ (medium dose) with ibuprofen $400 \mathrm{mg}$ alone; $16 / 24$ participants experienced at least $50 \%$ pain relief with the combination, and $11 / 23$ with ibuprofen alone (McQuay 1989). There were too few data for analysis. Two studies compared ibuprofen $400 \mathrm{mg}+$ codeine 60 mg (high dose) with ibuprofen $400 \mathrm{mg}$ alone; 56/81 participants experienced at least $50 \%$ pain relief with the combination, and 43/76 with ibuprofen alone (Cooper 1982; Sunshine 1987). For these three studies ibuprofen plus codeine was better than ibuprofen alone (Figure 5), although the difference only just reached statistical significance. 
Figure 5. Studies comparing ibuprofen plus codeine with same dose of ibuprofen, with the outcome of at least $50 \%$ maximum pain relief over 4 to 6 hours. Colour code: darker yellow - ibuprofen $200 \mathrm{mg}+$ codeine 20 mg versus ibuprofen $200 \mathrm{mg}$; lighter yellow - ibuprofen $400 \mathrm{mg}+$ codeine $60 \mathrm{mg}$ versus ibuprofen $400 \mathrm{mg}$.

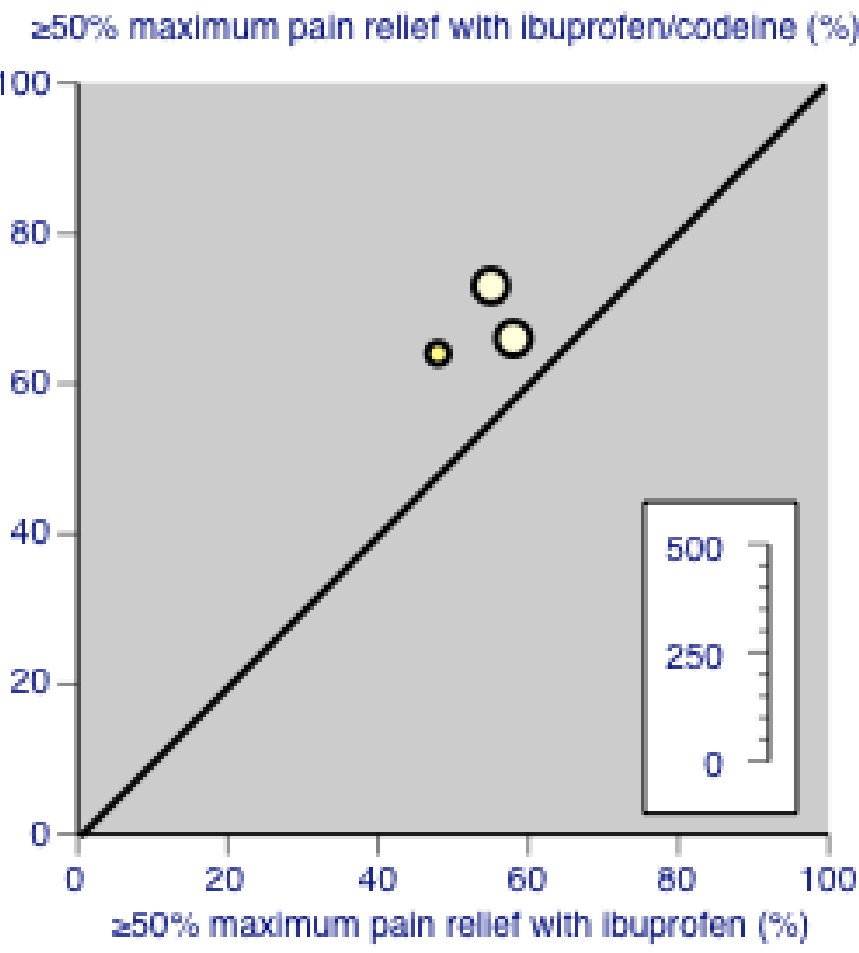

- The proportion of participants with $\geq 50 \%$ pain relief with ibuprofen $400 \mathrm{mg}+$ high dose codeine was 69\% (72/105, range $66 \%$ to $73 \%)$.

- The proportion of participants with $\geq 50 \%$ pain relief with ibuprofen alone was 55\% (54/99, range $48 \%$ to $58 \%)$.
- The relative benefit of the combination compared with the same dose of ibuprofen alone was 1.3 (1.01 to 1.6); the NNT was 7.1 (3.7 to 126). (Analysis 2.1; Figure 6).

Figure 6. Forest plot of comparison: ibuprofen + codeine (all doses; ibu/cod) versus same dose of ibuprofen alone (ibu), outcome: 3.1 Participants with at least 50\% pain relief.

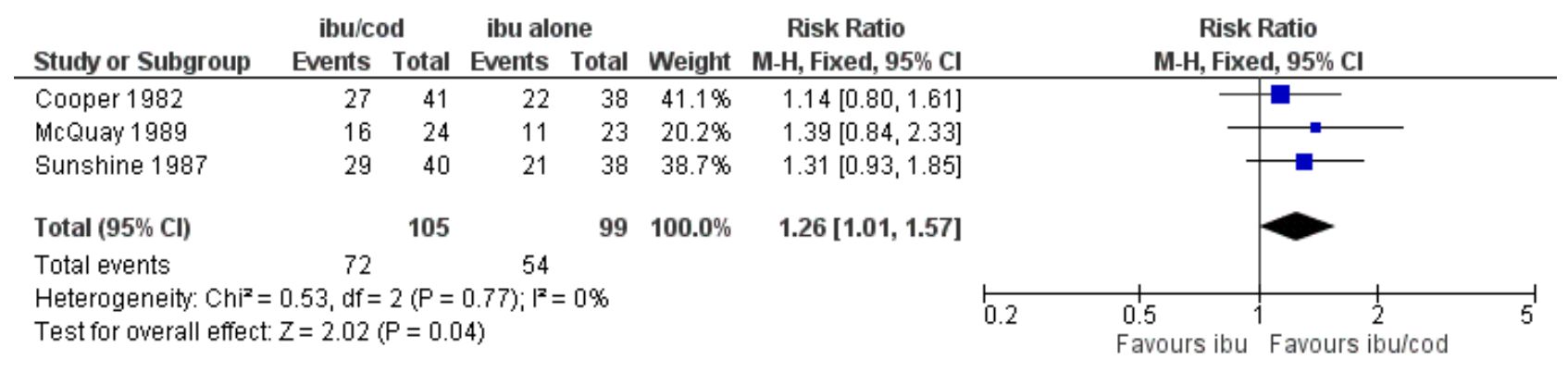

\section{Ibuprofen $400 \mathrm{mg}+$ codeine versus same dose of codeine alone}

Two studies (159 participants) compared ibuprofen $400 \mathrm{mg}$ + codeine $60 \mathrm{mg}$ (high dose) with codeine $60 \mathrm{mg}$ alone: $56 / 81$ participants experienced at least $50 \%$ pain relief with the combination, and 26/78 with codeine alone (Cooper 1982; Sunshine 1987). There were too few data for analysis.

\section{Subgroup analysis}

We carried out the planned subgroup analysis according to dose of both ibuprofen and codeine. There were insufficient data to allow any subgroup analysis by pain condition; most studies enrolled participants following dental surgery and one following gynaecological surgery (Sunshine 1987).

\section{Sensitivity analysis}

There were too few data for sensitivity analysis based on quality score (and all studies scored $\geq 3 / 5$ ).

In the analysis of ibuprofen $400 \mathrm{mg}+$ high dose codeine versus placebo, only one study had more than 50 participants in both 
treatment arms. Removing this study from the analysis did not significantly change the result (RR 2.7 (1.9 to 3.7); NNT 2.4 (1.8 to 3.3)).

\section{Time to use of rescue medication}

One study reported the median time to use of rescue medication, which was 8.1 hours for ibuprofen $400 \mathrm{mg}+$ codeine $26.5 \mathrm{mg}$ compared with 1.7 hours for placebo (data from 224 participants) (Daniels 2011).

One study reported the mean time to use of rescue medication, which was 3.7 hours for ibuprofen $400 \mathrm{mg}$ + codeine $60 \mathrm{mg}, 3.8$ hours for ibuprofen $400 \mathrm{mg}$ alone, and 2.4 hours for placebo (data from 125 participants) (Cooper 1982).

\section{Participants using rescue medication}

Two studies reported the number of participants using rescue medication within four to five hours of the intervention. In both studies the number using rescue medication was greater in the placebo group than the combination group for all doses, by a factor of two or more (data from 230 participants) (Frame 1986; Sunshine 1987).

\section{Adverse events}

All studies reported the number of participants experiencing any adverse event, but the two studies using multiple doses did not provide data for the first dose only (McQuay 1989; Petersen 1993).

Event rates in studies using a single dose varied considerably in both the active and control treatment arms. Four studies had treatment arms using ibuprofen $400 \mathrm{mg}$ + high-dose codeine (25.6 mg to 60 mg) (Cooper 1982; Daniels 2011; Frame 1986; Sunshine 1987).

- The proportion of participants experiencing any adverse event with ibuprofen $400 \mathrm{mg}$ + high-dose codeine was $28 \%$ (78/276, range $0 \%$ to $35 \%)$.

- The proportion of participants experiencing any adverse event with placebo was $18 \%$ (31/167, range $0 \%$ to $38 \%$ ).

- The RR of treatment compared with placebo was 1.2 (0.84 to 1.7); the NNH was not calculated (Analysis 1.2).

Only one study provided single dose data for the combination compared with the same dose of ibuprofen alone; $6 / 40$ participants experienced adverse events with ibuprofen $200 \mathrm{mg}+$ codeine 30 $\mathrm{mg}, 2 / 40$ with ibuprofen $400 \mathrm{mg}+$ codeine $60 \mathrm{mg}$, and 4/38 with ibuprofen $400 \mathrm{mg}$ alone (Sunshine 1987).

\section{Serious adverse events}

All studies reported that there were no serious adverse events.

\section{Withdrawals}

Withdrawals due to lack of efficacy have been considered under 'Use of rescue medication' (above) and were not consistently reported.

There were no adverse event withdrawals.

\section{DISCUSSION}

The background to this review is a knowledge that combinations of different analgesics provide additive effects in acute pain and migraine (Moore 2011b; Moore 2012). The aim was to assess the analgesic efficacy of ibuprofen and codeine combination analgesics because the combination is widely available to the public without prescription, and used to some extent in treating acute pain in hospital or in primary care. The differentiating factor is usually the dose of codeine, with lower doses of codeine in nonprescription medicines, and higher doses of codeine in prescription medicines; typically doses of codeine above $30 \mathrm{mg}$ are associated with prescription medicines. The review therefore sought evidence according to the dose of codeine used: low $(<10 \mathrm{mg})$, medium (10 $\mathrm{mg}$ to $20 \mathrm{mg}$ ), or high (> $20 \mathrm{mg}$ ) doses.

In the UK no combination analgesic preparations are available without prescription that contain a higher dose of codeine than $12.8 \mathrm{mg}$ codeine phosphate (equivalent to $10 \mathrm{mg}$ codeine base per tablet). To obtain higher codeine doses, as used in some of the studies identified, would require the prescription of the individual components rather than a combination preparation.

\section{Summary of main results}

We found no data relating to low-dose codeine, limited data relating to medium-dose codeine, and most of the available data related to high-dose codeine ( $25.6 \mathrm{mg}$ to $60 \mathrm{mg}$ ). The combination of ibuprofen $400 \mathrm{mg}$ plus high-dose codeine produced high rates of patients with good pain relief, in the range of $62 \%$ to $73 \%$ compared with $4 \%$ to $38 \%$ with placebo, though the actual dose of codeine did not appear to greatly influence the overall benefits of the combination in the limited data set available (Figure 4). The absolute difference of $46 \%$ gave an NNT for at least $50 \%$ pain relief over four to six hours of 2.2 (1.8 to 2.6), which is one of the lower (better) NNTs obtained from comparable data in an overview of acute pain studies (Moore 2011a). Based on limited data, ibuprofen plus codeine was better than the same dose of either drug alone.

\section{Overall completeness and applicability of evidence}

The main limitation of the review was the small number of studies and participants for some combinations. However, the general results are in accord with those known for ibuprofen and codeine (Derry 2009; Derry 2010) and for combination drugs in acute pain (Moore 2011b; Moore 2012).

The limited number of studies and participants did not allow for any sensible assessment of common or rare adverse events, although both ibuprofen and codeine are widely studied drugs. Serious morbidity, mainly gastrointestinal haemorrhage and opioid dependence, have been reported with ibuprofen-codeine combination products (Frei 2010). These patients were taking mean daily doses of $435 \mathrm{mg}$ to $602 \mathrm{mg}$ of codeine phosphate and 6800 $\mathrm{mg}$ to $9400 \mathrm{mg}$ of ibuprofen. Most of these patients had no previous history of substance use disorder, although similar issues have been reported for a small group with previous history of alcohol dependence (Robinson 2010).

The nature of this review, evaluating single-dose effectiveness, means that issues of misuse of codeine combination products cannot be dealt with directly. There clearly is a problem with this in some parts of the world, particularly in Australasia (Frei 2010; McAvoy 2011; Pilgrim 2013). 


\section{Quality of the evidence}

The studies themselves were of high quality but sample sizes were somewhat limited.

\section{Potential biases in the review process}

We carried out extensive searches to identify relevant studies but there always remains the possibility of unidentified studies. We calculated that for ibuprofen $400 \mathrm{mg}$ plus codeine $25.6 \mathrm{mg}$ to $60 \mathrm{mg}$, an additional 1168 participants would have to have been involved in unpublished trials with zero treatment effects for the NNT for at least $50 \%$ pain relief to increase above 8 , a level we consider to be the limit of clinical utility for this outcome (Moore 2008). It is unlikely that this amount of unidentified information exists.

We know of no other potential biases in the review process.

\section{Agreements and disagreements with other studies or reviews}

We found only one previous systematic review of ibuprofen plus codeine (Li Wan Po 1998). That review included eight studies comparing ibuprofen plus codeine versus placebo, several of which we excluded because of methodological issues (Cater 1985; Giles 1985; Norman 1985). It also included five studies comparing ibuprofen plus codeine versus ibuprofen. The present review included one large study not available in 1998 (Daniels 2011). Despite some differences in approach, the findings of the two reviews were remarkably similar in terms of treatment efficacy for ibuprofen plus codeine versus placebo, and for ibuprofen plus codeine versus ibuprofen.

\section{AUTHORS' CONCLUSIONS}

\section{Implications for practice}

Since the last version of this review was published in 2013 we identified no new studies.

Combinations of ibuprofen plus codeine are good analgesics and are probably better than either drug alone. The particular combination of ibuprofen $400 \mathrm{mg}$ plus codeine $25.6 \mathrm{mg}$ to $60 \mathrm{mg}$ demonstrates good efficacy. Use of combination analgesics that contain codeine has been a source of some concern because of misuse from over-the-counter preparations.

\section{Implications for research}

It is not clear what the implications are for research. Studies offer no new methodological insights, and, while additional data are always welcome, there are potential ethical issues from including participants in studies that do not add to existing knowledge in a meaningful way.

\section{ACKNOWLEDGEMENTS}

This review received infrastructure support from the Oxford Pain Relief Trust.

CRG Funding Acknowledgement: The National Institute for Health Research (NIHR) is the largest single funder of the Cochrane Pain, Palliative and Supportive Care Review Group. Disclaimer: The views and opinions expressed therein are those of the authors and do not necessarily reflect those of the NIHR, National Health Service, or the Department of Health. 


\section{RE F E R E N C E S}

\section{References to studies included in this review}

Cooper 1982 \{published data only\}

Cooper SA, Engel J, Ladov M, Precheur H, Rosenheck A, Rauch D. Analgesic efficacy of an ibuprofen-codeine combination. Pharmacotherapy 1982;2(3):162-7.

\section{Daniels 2011 \{published data only\}}

Daniels SE, Goulder MA, Aspley S, Reader S. A randomised, five-parallel-group, placebo-controlled trial comparing the efficacy and tolerability of analgesic combinations including a novel single-tablet combination of ibuprofen/paracetamol for postoperative dental pain. Pain 2011;152(3):632-42. [DOI: 10.1016/j.pain.2010.12.012]

\section{Frame 1986 \{published data only\}}

Frame JW, Fisher SE, Pickvance NJ, Skene AM. A doubleblind placebo-controlled comparison of three ibuprofen/ codeine combinations and aspirin. British Journal of Oral and Maxillofacial Surgery 1986;24(2):122-9.

\section{McQuay 1989 \{published data only\}}

McQuay HJ, Carroll D, Watts PG, Juniper RP, Moore RA. Codeine $20 \mathrm{mg}$ increases pain relief from ibuprofen $400 \mathrm{mg}$ after third molar surgery. A repeat-dosing comparison of ibuprofen and an ibuprofen-codeine combination. Pain 1989;37(1):7-13.

\section{Petersen 1993 \{published data only\}}

Petersen JK, Hansson F, Strid S. The effect of an ibuprofencodeine combination for the treatment of patients with pain after removal of lower third molars. Journal of Oral and Maxillofacial Surgery 1993;51(6):637-40.

\section{Sunshine 1987 \{published data only\}}

Sunshine A, Roure C, Olson N, Laska EM, Zorrilla C, Rivera J. Analgesic efficacy of two ibuprofen-codeine combinations for the treatment of postepisiotomy and postoperative pain. Clinical Pharmacology and Therapeutics 1987;42(4):374-80.

\section{References to studies excluded from this review}

Carlos 1989 \{published data only\}

Carlos R, Sánchez J, González B, Costela JL, Torres A, Galdo JR. Comparative study of two combinations of ibuprofencodeine versus its separate components in the treatment of postoperative pain. Revista Española de Anestesiología y Reanimación 1989;36 Suppl 1:48-9.

\section{Cater 1985 \{published data only\}}

Cater M, Brien PM, Pickvance NJ. A double-blind comparison of the new ibuprofen-codeine phosphate combination, zomepirac, and placebo in the relief of postepisiotomy pain. Clinical Therapeutics 1985;7:442-7.

\section{Giles 1985 \{published data only\}}

Giles AD, Pickvance NJ. Combination analgesia following oral surgery - a double-blind comparison of ibuprofen, codeine phosphate and two combination ratios. Clinical Trials Journal 1985;22:300-13.
Giles 1986 \{published data only\}

Giles AD, Hill CM, Shepherd JP, Stewart DJ, Pickvance NJ. A single dose assessment of an ibuprofen/codeine combination in postoperative dental pain. International Journal of Oral and Maxillofacial Surgery 1986;15:727-32.

Hellman 1992 \{published data only\}

Hellman M, Ahlström U, Andersson L, Strid S. Analgesic efficacy of an ibuprofen-codeine combination in patients with pain after removal of lower third molars. European Journal of Clinical Pharmacology 1992;43(4):347-50.

\section{McQuay 1992 \{published data only\}}

McQuay HJ, Carroll D, Guest P, Juniper RP, Moore RA. A multiple dose comparison of combinations of ibuprofen and codeine and paracetamol, codeine and caffeine after third molar surgery. Anaesthesia 1992;47(8):672-7.

\section{Norman 1985 \{published data only\}}

Norman SL, Jeavons BI, O'Brien PM, Johnson IR, Hitchcock A, Noyelle RM, et al. A double-blind comparison of a new ibuprofen-codeine phosphate combination, codeine phosphate, and placebo in the relief of postepisiotomy pain. Clinical Therapeutics 1985;7:549-54.

\section{Walton 1990 \{published data only\}}

Walton GM, Rood JP. A comparison of ibuprofen and ibuprofencodeine combination in the relief of post-operative oral surgery pain. British Dental Journal 1990;169(8):245-7.

\section{Additional references}

\section{Barden 2004}

Barden J, Edwards JE, McQuay HJ, Moore RA. Pain and analgesic response after third molar extraction and other postsurgical pain. Pain 2004;107(1-2):86-90. [DOI: 10.1016/ j.pain.2003.09.021]

\section{Cascarbi 2003}

Cascarbi I. Pharmacogenetics of cytochrome P4502D6: genetic background and clinical implication. European Journal of Clinical Investigation 2003;33 Suppl 2:17-22.

\section{Chaparro 2012}

Chaparro LE, Wiffen PJ, Moore RA, Gilron I. Combination pharmacotherapy for the treatment of neuropathic pain in adults. Cochrane Database of Systematic Reviews 2012, Issue 7. [DOI: 10.1002/14651858.CD008943.pub2]

\section{Clarke 2012}

Clarke R, Derry S, Moore RA, McQuay HJ. Single dose oral etoricoxib for acute postoperative pain in adults. Cochrane Database of Systematic Reviews 2012, Issue 4. [DOI: 10.1002/14651858.CD004309.pub3] 


\section{Collins 1997}

Collins SL, Moore RA, McQuay HJ. The visual analogue pain intensity scale: what is moderate pain in millimetres?. Pain 1997;72:95-7. [DOI: 10.1016/S0304-3959(97)00005-5]

\section{Collins 2001}

Collins SL, Edwards J, Moore RA, Smith LA, McQuay HJ. Seeking a simple measure of analgesia for mega-trials: is a single global assessment good enough?. Pain 2001;91(1-2):189-94. [DOI: 10.1016/S0304-3959(00)00435-8]

\section{Cook 1995}

Cook RJ, Sackett DL. The number needed to treat: a clinically useful measure of treatment effect. BMJ 1995;310:452-4.

\section{Cooper 1991}

Cooper SA. Single-dose analgesic studies: the upside and downside of assay sensitivity. In: Max MB, Portenoy RK, Laska EM editor(s). The design of analgesic clinical trials. Advances in Pain Research and Therapy. Vol. 18, New York: Raven Press, 1991:117-24.

\section{Derry 2009}

Derry C, Derry S, Moore RA, McQuay HJ. Single dose oral ibuprofen for acute postoperative pain in adults. Cochrane Database of Systematic Reviews 2009, Issue 3. [DOI: 10.1002/14651858.CD001548.pub2]

\section{Derry 2010}

Derry S, Moore RA, McQuay HJ. Single dose oral codeine, as a single agent, for acute postoperative pain in adults. Cochrane Database of Systematic Reviews 2010, Issue 4. [DOI: 10.1002/14651858.CD008099.pub2]

\section{Deschartres 2013}

Dechartres A, Trinquart L, Boutron I, Ravaud P. Influence of trial sample size on treatment effect estimates: metaepidemiological study. BMJ 2013;346:f2304. [DOI: 10.1136/ bmj.f2304]

\section{FitzGerald 2001}

FitzGerald GA, Patrono C. The coxibs, selective inhibitors of cyclooxygenase-2. New England Journal of Medicine 2001;345(6):433-42. [DOI: 10.1056/NEJM200108093450607]

\section{Forrest 2002}

Forrest JB, Camu F, Greer IA, Kehlet H, Abdalla M, Bonnet F. Ketorolac, diclofenac, and ketoprofen are equally safe for pain relief after major surgery. British Journal of Anaesthesia 2002;88(2):227-33. [DOI: 10.1093/bja/88.2.227]

\section{Frei 2010}

Frei MY, Nielsen S, Dobbin MD, Tobin CL. Serious morbidity associated with misuse of over-the-counter codeine-ibuprofen analgesics: a series of 27 cases. Medical Journal of Australia 2010;193(5):294-6.

\section{Hernandez-Diaz 2001}

Hernández-Díaz S, García-Rodríguez LA. Epidemiologic assessment of the safety of conventional nonsteroidal anti- inflammatory drugs. The American Journal of Medicine 2001;110 Suppl 3A:20S-7S. [DOI: 10.1016/S0002-9343(00)00682-3]

\section{Higgins 2011}

Higgins JPT, Altman DG, Sterne JAC. Chapter 8: Assessing risk of bias in included studies. In: Higgins JPT, Green S editor(s). Cochrane Handbook for Systematic Reviews of Interventions Version 5.1.0 [updated March 2011]. Available from www.cochrane-handbook.org.

\section{Jadad 1996a}

Jadad AR, Carroll D, Moore A, McQuay H. Developing a database of published reports of randomised clinical trials in pain research. Pain 1996;66:239-46. [DOI: 10.1016/0304-3959(96)03033-3]

\section{Jadad 1996b}

Jadad AR, Moore RA, Carroll D, Jenkinson C, Reynolds DJM, Gavaghan DJ, McQuay HJ. Assessing the quality of reports of randomized clinical trials: is blinding necessary?. Controlled Clinical Trials 1996;17:1-12. [DOI: 10.1016/0197-2456(95)00134-4]

\section{L'Abbé 1987}

L'Abbé KA, Detsky AS, O'Rourke K. Meta-analysis in clinical research. Annals of Internal Medicine 1987;107:224-33.

\section{Li Wan Po 1998}

Li Wan Po A, Zhang WY. Analgesic efficacy of ibuprofen alone and in combination with codeine or caffeine in postsurgical pain: a meta-analysis. European Journal of Clinical Pharmacology 1998;53(5):303-11.

\section{McAvoy 2011}

McAvoy BR, Dobbin MD, Tobin CL. Over-the-counter codeine analgesic misuse and harm: characteristics of cases in Australia and New Zealand. New Zealand Medical Journal 2011;124(1346):29-33.

\section{McQuay 2005}

McQuay HJ, Moore RA. Placebo. Postgraduate Medical Journal 2005;81:155-60. [DOI: 10.1136/pgmj.2004.024737]

\section{Moore 1996}

Moore A, McQuay H, Gavaghan D. Deriving dichotomous outcome measures from continuous data in randomised controlled trials of analgesics. Pain 1996;66(2-3):229-37. [DOI: 10.1016/0304-3959(96)03032-1]

\section{Moore 1997a}

Moore A, McQuay H, Gavaghan D. Deriving dichotomous outcome measures from continuous data in randomised controlled trials of analgesics: Verification from independent data. Pain 1997;69(1-2):127-30. [DOI: 10.1016/ S0304-3959(96)03251-4]

\section{Moore 1997b}

Moore A, Moore O, McQuay H, Gavaghan D. Deriving dichotomous outcome measures from continuous data in randomised controlled trials of analgesics: Use of pain intensity 
and visual analogue scales. Pain 1997;69(3):311-5. [DOI: 10.1016/S0304-3959(96)03306-4]

\section{Moore 1998}

Moore RA, Gavaghan D, Tramer MR, Collins SL, McQuay HJ. Size is everything-large amounts of information are needed to overcome random effects in estimating direction and magnitude of treatment effects. Pain 1998;78(3):209-16. [DOI: 10.1016/S0304-3959(98)00140-7]

\section{Moore 2003}

Moore RA, Edwards J, Barden J, McQuay HJ. Bandolier's Little Book of Pain. Oxford: Oxford University Press, 2003. [ISBN: 0-19-263247-7]

\section{Moore 2005}

Moore RA, Edwards JE, McQuay HJ. Acute pain: individual patient meta-analysis shows the impact of different ways of analysing and presenting results. Pain 2005;116(3):322-31. [DOI: 10.1016/j.pain.2005.05.001]

\section{Moore 2006}

Moore A, McQuay H. Bandolier's Little Book of Making Sense of the Medical Evidence. Oxford: Oxford University Press, 2006. [ISBN: 0-19-856604-2]

\section{Moore 2008}

Moore RA, Barden J, Derry S, McQuay HJ. Managing potential publication bias. In: McQuay HJ, Kalso E, Moore RA editor(s). Systematic Reviews in Pain Research: Methodology Refined. Seattle: IASP Press, 2008:15-23. [ISBN: 978-0-931092-69-5]

\section{Moore 2011a}

Moore RA, Derry S, McQuay HJ, Wiffen PJ. Single dose oral analgesics for acute postoperative pain in adults. Cochrane Database of Systematic Reviews 2011, Issue 9. [DOI: 10.1002/14651858.CD008659.pub2]

\section{Moore 2011b}

Moore RA, Straube S, Paine J, Derry S, McQuay HJ. Minimum efficacy criteria for comparisons between treatments using individual patient meta-analysis of acute pain trials: examples of etoricoxib, paracetamol, ibuprofen, and ibuprofen/ paracetamol combinations after third molar extraction. Pain 2011;152(5):982-9. [DOI: 10.1016/j.pain.2010.11.030]

\section{Moore 2012}

Moore RA, Derry CJ, Derry S, Straube S, McQuay HJ. A conservative method of testing whether combination analgesics produce additive or synergistic effects using evidence from acute pain and migraine. European Journal of Pain 2012;16(4):585-91. [DOI: 10.1016/j.ejpain.2011.08.009]

\section{Moore 2013}

Moore A, Derry S, Eccleston C, Kalso E. Expect analgesic failure; pursue analgesic success. BMJ 2013;346:f2690. [DOI: 10.1136/ bmj.f2690]

\section{Morris 1995}

Morris JA, Gardner MJ. Calculating confidence intervals for relative risk, odds ratios and standardised ratios and rates. In: Gardner MJ, Altman DG editor(s). Statistics with confidence confidence intervals and statistical guidelines. London: British Medical Journal, 1995:50-63.

\section{Nüesch 2010}

Nüesch E, Trelle S, Reichenbach S, Rutjes AW, Tschannen B, Altman DG, et al. Small study effects in meta-analyses of osteoarthritis trials: meta-epidemiological study. BMJ 2010;341:c3515. [DOI: 10.1136/bmj.c3515]

\section{Pilgrim 2013}

Pilgrim JL, Dobbin M, Drummer OH. Fatal misuse of codeineibuprofen analgesics in Victoria, Australia. Medical Journal of Australia 2013;199(5):329-31. [DOI: 10.5694/mja12.11843]

\section{Rapoport 1999}

Rapoport RJ. The safety of NSAIDs and related drugs for the management of acute pain: Maximizing benefits and minimizing risks. Cancer Control 1999;6(2 Suppl 1):18-21.

\section{RevMan 2011 [Computer program]}

The Nordic Cochrane Centre, The Cochrane Collaboration. Review Manager (RevMan). Version 5.1. Copenhagen: The Nordic Cochrane Centre, The Cochrane Collaboration, 2011.

\section{Robinson 2010}

Robinson GM, Robinson S, McCarthy P, Cameron C. Misuse of over-the-counter codeine-containing analgesics: dependence and other adverse effects. New Zealand Medical Journal 2010;123(1317):59-64.

\section{Toms 2008}

Toms L, McQuay HJ, Derry S, Moore RA. Single dose oral paracetamol (acetaminophen) for postoperative pain in adults. Cochrane Database of Systematic Reviews 2008, Issue 4. [DOI: 10.1002/14651858.CD004602.pub2]

\section{Toms 2009}

Toms L, Derry S, Moore RA, McQuay HJ. Single dose oral paracetamol (acetaminophen) with codeine for postoperative pain in adults. Cochrane Database of Systematic Reviews 2009, Issue 1. [DOI: 10.1002/14651858.CD001547.pub2]

\section{Tramèr 1997}

Tramèr MR, Reynolds DJM, Moore RA, McQuay HJ. Impact of covert duplicate results on meta-analysis: a case study. BMJ 1997;315:635-9. [DOI: 10.1136/bmj.315.7109.635]

\section{References to other published versions of this review Derry 2013}

Derry S, Karlin SM, Moore RA. Single dose oral ibuprofen plus codeine for acute postoperative pain in adults. Cochrane Database of Systematic Reviews 2013, Issue 3. [DOI: 10.1002/14651858.CD010107.pub2] 
CHARACTERISTICS OF STUDIES

Characteristics of included studies [ordered by study ID]

Cooper 1982

Methods $\quad$ DB, 6 parallel groups. Single oral dose
Medication administered when baseline pain reached a moderate to severe intensity
Pain assessed at $0,1,2,3,4 \mathrm{~h}$

Pain assessed at 0, 1, 2, 3, $4 \mathrm{~h}$

\begin{tabular}{|c|c|}
\hline \multirow[t]{4}{*}{ Participants } & Surgical removal of 1 to 4 impacted third molars \\
\hline & $N=249$ \\
\hline & $M=83, F=166$ \\
\hline & Mean age 23 years \\
\hline
\end{tabular}

\begin{tabular}{ll}
\hline Interventions & Ibuprofen + codeine $400 / 60 \mathrm{mg}, \mathrm{n}=41$ \\
& Ibuprofen $400 \mathrm{mg}, \mathrm{n}=38$ \\
& Aspirin/codeine $650 \mathrm{mg} / 60 \mathrm{mg}, \mathrm{n}=45$ \\
& Aspirin $650 \mathrm{mg}, \mathrm{n}=38$ \\
& Codeine $60 \mathrm{mg}, \mathrm{n}=41$ \\
& Placebo, $\mathrm{n}=46$
\end{tabular}

PI: standard 4-point scale
PR: standard 5-point scale
PGE: standard 5-point scale
Use of rescue medication
Adverse events
Withdrawals

Notes Oxford Quality Score: R1, DB2, W1. Total = 4/5

Rescue medication allowed after $1 \mathrm{~h}$

\section{Risk of bias}

\begin{tabular}{lll}
\hline Bias & Authors' judgement & Support for judgement \\
\hline $\begin{array}{l}\text { Random sequence genera- } \\
\text { tion (selection bias) }\end{array}$ & Unclear risk & Not described \\
\hline $\begin{array}{l}\text { Allocation concealment } \\
\text { (selection bias) }\end{array}$ & Low risk & $\begin{array}{l}\text { Pharmaceutical company held randomisation code and packaged bottles, } \\
\text { which were identified by sequential code number only }\end{array}$ \\
\hline $\begin{array}{l}\text { Blinding of participants } \\
\text { and personnel (perfor- } \\
\text { mance bias) } \\
\text { All outcomes }\end{array}$ & Low risk & Tablets "appeared identical for every patient" \\
\hline
\end{tabular}


Cooper 1982 (Continued)

Blinding of outcome as- Low risk Tablets "appeared identical for every patient" sessment (detection bias)

All outcomes

\begin{tabular}{ll}
\hline Size $\quad$ High risk $\quad<50$ participants per treatment group \\
\hline
\end{tabular}

Daniels 2011

Methods $\quad$ R, DB, 5 parallel groups. Single oral dose

Medication administered when baseline pain reached a moderate to severe intensity, and $\geq 50 / 100 \mathrm{~mm}$

Pain assessed at baseline then $0.25,0.5,0.75,1,1.5,2 \mathrm{~h}$ and hourly to $12 \mathrm{~h}$

\begin{tabular}{ll}
\hline Participants & Surgical removal of $\geq 3$ impacted third molars (2 mandibular) \\
$\mathrm{N}=678$ & $\mathrm{M}=271, \mathrm{~F}=407$ \\
& Mean age 20 years \\
\hline Interventions & Ibuprofen $400 \mathrm{mg}+$ codeine $25.6 \mathrm{mg}, \mathrm{n}=169$ \\
& Paracetamol $1,000 \mathrm{mg}+$ codeine $30 \mathrm{mg}, \mathrm{n}=113$ \\
& Ibuprofen $200 \mathrm{mg}+$ paracetamol $500 \mathrm{mg}, \mathrm{n}=173$ \\
& Ibuprofen $400 \mathrm{mg}+$ paracetamol $1000 \mathrm{mg}, \mathrm{n}=168$ \\
& Placebo, $\mathrm{n}=55$ \\
\hline Outcomes & Pl: standard 4-point scale \\
& PR: standard 5-point scale \\
& PGE: standard 5-point scale \\
& Use of rescue medication \\
& Adverse events \\
Withdrawals
\end{tabular}

Notes Oxford Quality Score: R2, DB2, W1. Total = 5/5

Rescue medication (tramadol if $<4 \mathrm{~h}$, paracetamol/hydrocodone if $4 \mathrm{~h}+$ ) allowed after $1.5 \mathrm{~h}$

\section{Risk of bias}

\begin{tabular}{lll}
\hline Bias & Authors' judgement & Support for judgement \\
\hline $\begin{array}{l}\text { Random sequence genera- } \\
\text { tion (selection bias) }\end{array}$ & Low risk & "computer-generated system" \\
\hline $\begin{array}{l}\text { Allocation concealment } \\
\text { (selection bias) }\end{array}$ & Unclear risk & Not described \\
\hline $\begin{array}{l}\text { Blinding of participants } \\
\text { and personnel (perfor- } \\
\text { mance bias) }\end{array}$ & Low risk & "Each treatment consisted of 2 white tablets of a similar size and was adminis- \\
All outcomes & & tered as a single dose taken with approximately 300 mL of water" \\
\hline
\end{tabular}


Daniels 2011 (Continued)
Blinding of outcome as-
Low risk
"Each treatment consisted of 2 white tablets of a similar size and was adminis- sessment (detection bias) tered as a single dose taken with approximately $300 \mathrm{~mL}$ of water"
All outcomes

\begin{tabular}{ll}
\hline Size $\quad$ Unclear risk & 50 to 199 participants per treatment arm \\
\hline
\end{tabular}

Frame 1986

\begin{tabular}{|c|c|}
\hline Methods & $\begin{array}{l}\mathrm{R}, \mathrm{DB} \text {, single oral dose, parallel groups } \\
\text { Medication administered when baseline pain reached a moderate to severe intensity } \\
\text { Assessed at } 0,1,2,3,4,5 \mathrm{~h}\end{array}$ \\
\hline Participants & $\begin{array}{l}\text { Surgical removal of impacted third molar } \\
N=135 \\
M / F \text { "balanced" but numbers not provided } \\
\text { Mean age } 24 \text { years }\end{array}$ \\
\hline Interventions & $\begin{array}{l}\text { Ibuprofen } 200 \mathrm{mg}+\text { codeine } 15 \mathrm{mg}, \mathrm{n}=32 \\
\text { Ibuprofen } 400 \mathrm{mg}+\text { codeine } 30 \mathrm{mg}, \mathrm{n}=26 \\
\text { Ibuprofen } 800 \mathrm{mg}+\text { codeine } 60 \mathrm{mg}, \mathrm{n}=26 \\
\text { Aspirin } 600 \mathrm{mg}, \mathrm{n}=25 \\
\text { Placebo } \mathrm{n}=26\end{array}$ \\
\hline Outcomes & $\begin{array}{l}\text { PI: non-standard 9-point scale } \\
\text { PR: standard 5-point scale } \\
\text { Global assessment (no scale reported) } \\
\text { Use of rescue medication } \\
\text { Adverse events } \\
\text { Withdrawals }\end{array}$ \\
\hline
\end{tabular}

Notes Oxford Quality Score: $R=1, D B=2, W=1$. Total $=4 / 5$

Rescue medication (paracetamol) allowed after $2 \mathrm{~h}$

\section{Risk of bias}

\begin{tabular}{lll}
\hline Bias & Authors' judgement & Support for judgement \\
\hline $\begin{array}{l}\text { Random sequence genera- } \\
\text { tion (selection bias) }\end{array}$ & Unclear risk & Not described \\
\hline $\begin{array}{l}\text { Allocation concealment } \\
\text { (selection bias) }\end{array}$ & Low risk & Sealed sachets \\
\hline $\begin{array}{l}\text { Blinding of participants } \\
\text { and personnel (perfor- } \\
\text { mance bias) } \\
\begin{array}{l}\text { All outcomes } \\
\hline\end{array}\end{array}$ & Low risk & "aspirin specially formulated to match the other drugs" \\
\hline
\end{tabular}

\begin{tabular}{l}
$\begin{array}{l}\text { Blinding of outcome as- } \\
\text { sessment (detection bias) }\end{array} \quad$ Low risk "aspirin specially formulated to match the other drugs" \\
\hline
\end{tabular}


Frame 1986 (Continued)

All outcomes

\begin{tabular}{ll}
\hline Size $\quad$ High risk & $<50$ participants per treatment arm \\
\hline
\end{tabular}

\section{McQuay 1989}

Methods Randomised, double-blind, 2-group cross-over, multiple dose (data reported for first dose)

Medication administered when baseline pain reached a moderate to severe intensity

Assessed at 0, 0.5, 1, 2, 3, 4, 5, $6 \mathrm{~h}$

\begin{tabular}{|c|c|c|}
\hline Participants & \multicolumn{2}{|c|}{$\begin{array}{l}\text { Surgical removal of impacted mandibular third molar (one at each phase of cross-over) } \\
\begin{array}{l}N=25 \\
M=6, F=19 \\
\text { Mean age } 24 \text { years }\end{array}\end{array}$} \\
\hline Interventions & \multicolumn{2}{|c|}{$\begin{array}{l}\text { Ibuprofen } 400 \mathrm{mg}+\text { codeine } 20 \mathrm{mg}, \mathrm{n}=25 \text { ( } 24 \text { analysed }) \\
\text { Ibuprofen } 400 \mathrm{mg}, \mathrm{n}=25 \text { ( } 23 \text { analysed })\end{array}$} \\
\hline Outcomes & $\begin{array}{l}\text { PI: standard 4-point sc } \\
\text { PR: standard 5-point s } \\
\text { PGE: standard 5-point } \\
\text { Adverse events } \\
\text { Withdrawals }\end{array}$ & $\begin{array}{l}\text { le and } 100 \mathrm{~mm} \text { VAS } \\
\text { ale and } 100 \mathrm{~mm} \text { VAS } \\
\text { cale }\end{array}$ \\
\hline Notes & \multicolumn{2}{|c|}{ Second dose available for inadequate pain relief } \\
\hline \multicolumn{3}{|l|}{ Risk of bias } \\
\hline Bias & Authors' judgement & Support for judgement \\
\hline $\begin{array}{l}\text { Random sequence genera- } \\
\text { tion (selection bias) }\end{array}$ & Unclear risk & Not described \\
\hline $\begin{array}{l}\text { Allocation concealment } \\
\text { (selection bias) }\end{array}$ & Unclear risk & Not described \\
\hline $\begin{array}{l}\text { Blinding of participants } \\
\text { and personnel (perfor- } \\
\text { mance bias) } \\
\text { All outcomes }\end{array}$ & Low risk & $\begin{array}{l}\text { "The white tablets were identifiable only by the patient and treatment num- } \\
\text { bers" }\end{array}$ \\
\hline $\begin{array}{l}\text { Blinding of outcome as- } \\
\text { sessment (detection bias) } \\
\text { All outcomes }\end{array}$ & Low risk & $\begin{array}{l}\text { "The white tablets were identifiable only by the patient and treatment num- } \\
\text { bers" }\end{array}$ \\
\hline Size & High risk & $<50$ participants per treatment arm \\
\hline
\end{tabular}




\section{Petersen 1993}

\begin{tabular}{|c|c|c|}
\hline Methods & \multicolumn{2}{|c|}{$\begin{array}{l}\mathrm{R}, \mathrm{DB}, 2 \text {-group cross-over, } 2 \text {-dose (data reported for first dose) (Due to carryover effects data analysed } \\
\text { as parallel study using first phase only) } \\
\text { Medication administered when baseline pain reached a moderate to severe intensity } \\
\text { Assessed at } 0,0.5,1,2,3,4,5,6 \mathrm{~h}\end{array}$} \\
\hline Participants & \multicolumn{2}{|c|}{$\begin{array}{l}\text { Surgical removal of impacted mandibular third molar (one at each phase of cross-over) } \\
N=60 \\
M=38, F=22 \\
\text { Mean age } 23 \text { years }\end{array}$} \\
\hline Interventions & \multicolumn{2}{|c|}{$\begin{array}{l}\text { Ibuprofen } 400 \mathrm{mg}+\text { codeine } 60 \mathrm{mg}, \mathrm{n}=29 \\
\text { Ibuprofen } 400 \mathrm{mg}, \mathrm{n}=31\end{array}$} \\
\hline Outcomes & \multicolumn{2}{|c|}{$\begin{array}{l}\text { PI: } 100 \text { mm VAS } \\
\text { Adverse events for both doses } \\
\text { Withdrawals }\end{array}$} \\
\hline Notes & \multicolumn{2}{|c|}{$\begin{array}{l}\text { Oxford Quality Score: } \mathrm{R}=1, \mathrm{DB}=2, \mathrm{~W}=1 . \text { Total }=4 / 5 \\
\text { Second dose available after } 2 \mathrm{~h} \text { for inadequate pain relief }\end{array}$} \\
\hline \multicolumn{3}{|l|}{ Risk of bias } \\
\hline Bias & Authors' judgement & Support for judgement \\
\hline $\begin{array}{l}\text { Random sequence genera- } \\
\text { tion (selection bias) }\end{array}$ & Unclear risk & Not described \\
\hline $\begin{array}{l}\text { Allocation concealment } \\
\text { (selection bias) }\end{array}$ & Unclear risk & Not described \\
\hline $\begin{array}{l}\text { Blinding of participants } \\
\text { and personnel (perfor- } \\
\text { mance bias) } \\
\text { All outcomes }\end{array}$ & Low risk & "All tablets were of identical appearance" \\
\hline $\begin{array}{l}\text { Blinding of outcome as- } \\
\text { sessment (detection bias) } \\
\text { All outcomes }\end{array}$ & Low risk & "All tablets were of identical appearance" \\
\hline Size & High risk & $<50$ participants per treatment arm \\
\hline
\end{tabular}

Sunshine 1987

\begin{tabular}{ll} 
Methods & R, DB, 5 parallel groups. Single oral dose \\
& Medication administered when baseline pain reached a moderate to severe intensity \\
& Pain assessed at $0,0.5,1,2,3,4 \mathrm{~h}$ \\
\hline Participants & Episiotomy, Caesarian section or gynaecological operations \\
$\mathrm{N}=195$
\end{tabular}


Sunshine 1987 (Continued)

$$
\begin{aligned}
& \text { All } F \\
& \text { Mean age } 26 \text { years }
\end{aligned}
$$

$\begin{array}{ll}\text { Interventions } & \text { Ibuprofen + codeine 200/30 mg, } \mathrm{n}=40 \\ & \text { Ibuprofen + codeine } 400 / 60 \mathrm{mg}, \mathrm{n}=40 \\ & \text { Ibuprofen } 40 \mathrm{mg}, \mathrm{n}=38 \\ & \text { Codeine } 60 \mathrm{mg}, \mathrm{n}=37 \\ & \text { Placebo, } \mathrm{n}=40\end{array}$

\begin{tabular}{ll}
\hline Outcomes & Pl: standard 4-point scale \\
PR: standard 5-point scale \\
Use of rescue medication \\
Adverse events \\
Withdrawals
\end{tabular}

Notes Oxford Quality Score: R1, DB2, W1. Total = 4/5

Rescue medication allowed after $1 \mathrm{~h}$

\section{Risk of bias}

\begin{tabular}{lll}
\hline Bias & Authors' judgement & Support for judgement \\
\hline $\begin{array}{l}\text { Random sequence genera- } \\
\text { tion (selection bias) }\end{array}$ & Unclear risk & Not described \\
\hline $\begin{array}{l}\text { Allocation concealment } \\
\text { (selection bias) }\end{array}$ & Unclear risk & Not described \\
\hline $\begin{array}{l}\text { Blinding of participants } \\
\text { and personnel (perfor- } \\
\text { mance bias) }\end{array}$ & Low risk & "All unit doses were identical in appearance and packaging" \\
$\begin{array}{l}\text { All outcomes } \\
\text { Blinding of outcome as- } \\
\text { sessment (detection bias) } \\
\begin{array}{l}\text { All outcomes } \\
\text { Size }\end{array}\end{array}$ & Unclear risk & "All unit doses were identical in appearance and packaging" \\
\hline
\end{tabular}

DB: double-blind; F: female; M: male; N: number of participants in study; n: number of participants in treatment arm; PGE: patient global evaluation; PI: pain intensity; PR: pain relief; R: randomised; VAS: visual analogue scale; W: withdrawals

\section{Characteristics of excluded studies [ordered by study ID]}

\begin{tabular}{ll}
\hline Study & Reason for exclusion \\
\hline Carlos 1989 & Short abstract \\
\hline Cater 1985 & Participants remedicating not correctly analysed (diaries continued) \\
\hline \hline
\end{tabular}




\begin{tabular}{ll}
\hline Study & Reason for exclusion \\
\hline Giles 1985 & Did not state which pain scale was used \\
\hline Giles 1986 & Inappropriate study design - data from participants remedicating were not handled correctly \\
\hline Hellman 1992 & No suitable (placebo or same dose of ibuprofen alone) comparator \\
\hline McQuay 1992 & No suitable (placebo or same dose of ibuprofen alone) comparator \\
\hline Norman 1985 & Participants remedicating not correctly analysed (diaries continued) \\
\hline Walton 1990 & Medication administered preoperatively \\
\hline
\end{tabular}

\section{DATA AND ANALYSES}

\section{Comparison 1. Ibuprofen $\mathbf{4 0 0} \mathbf{~ m g}+$ high dose codeine versus placebo}

\begin{tabular}{lllll}
\hline Outcome or subgroup title & No. of studies & $\begin{array}{l}\text { No. of partici- } \\
\text { pants }\end{array}$ & Statistical method & Effect size \\
\hline 1 Participants with $\geq 50 \%$ pain relief & 4 & 443 & $\begin{array}{l}\text { Risk Ratio (M-H, Fixed, 95\% } \\
\text { Cl) }\end{array}$ & $4.09[2.82,5.93]$ \\
\hline 2 Participants with any adverse event & 4 & 443 & $\begin{array}{l}\text { Risk Ratio (M-H, Fixed, 95\% } \\
\text { Cl) }\end{array}$ & $1.18[0.84,1.66]$ \\
\hline
\end{tabular}

\section{Analysis 1.1. Comparison $1 \mathrm{lbuprofen} 400 \mathrm{mg}+\mathrm{high}$ dose codeine versus placebo, Outcome 1 Participants with $\geq 50 \%$ pain relief.}

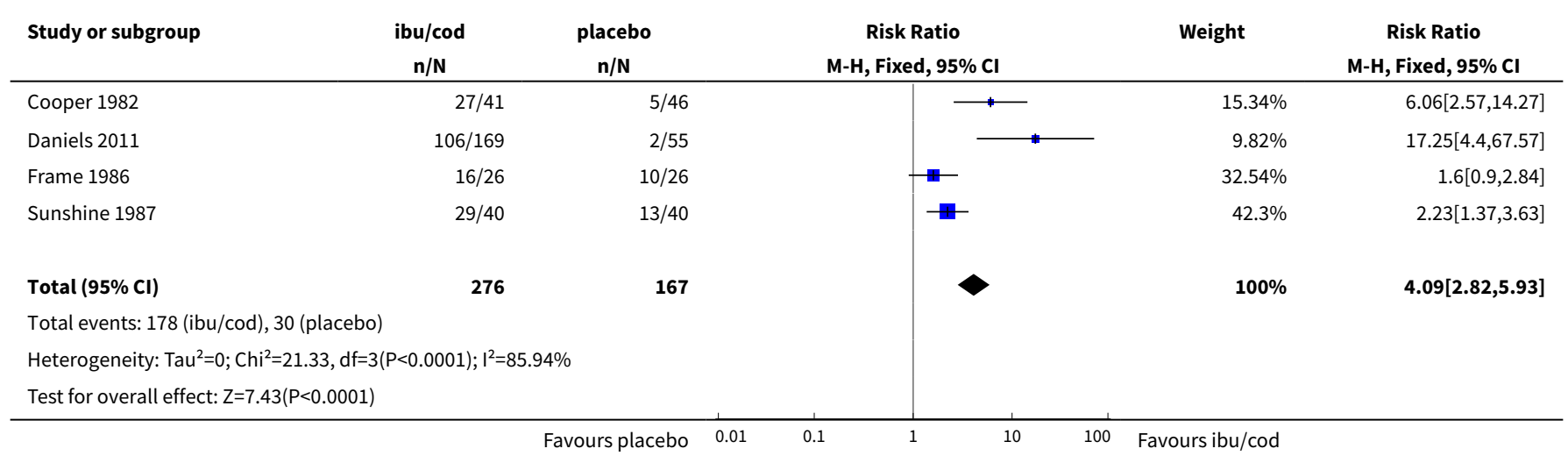


Analysis 1.2. Comparison $1 \mathrm{lbuprofen} 400 \mathrm{mg}+$ high dose codeine versus placebo, Outcome 2 Participants with any adverse event.

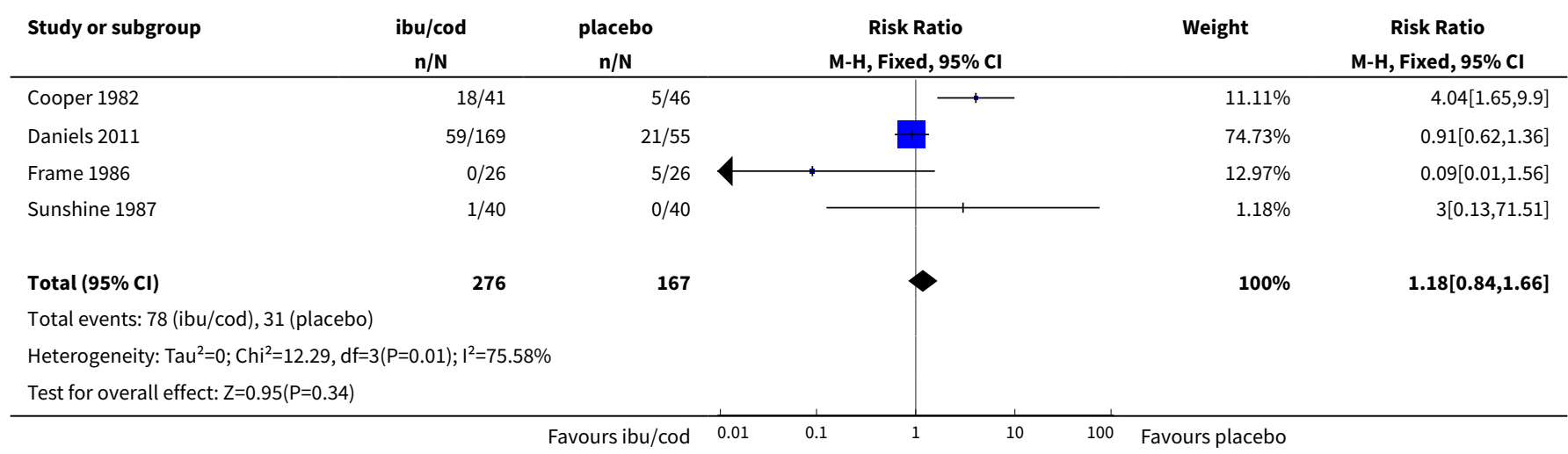

Comparison 2. Ibuprofen + codeine (all doses) versus same dose of ibuprofen alone

\begin{tabular}{lllll}
\hline Outcome or subgroup title & No. of studies & $\begin{array}{l}\text { No. of partici- } \\
\text { pants }\end{array}$ & Statistical method & Effect size \\
\hline 1 Participants with $\geq 50 \%$ pain relief & 3 & 204 & $\begin{array}{l}\text { Risk Ratio (M-H, Fixed, 95\% } \\
\text { Cl) }\end{array}$ & $1.26[1.01,1.57]$ \\
\hline
\end{tabular}

Analysis 2.1. Comparison 2 Ibuprofen + codeine (all doses) versus same dose of ibuprofen alone, Outcome 1 Participants with $\geq 50 \%$ pain relief.

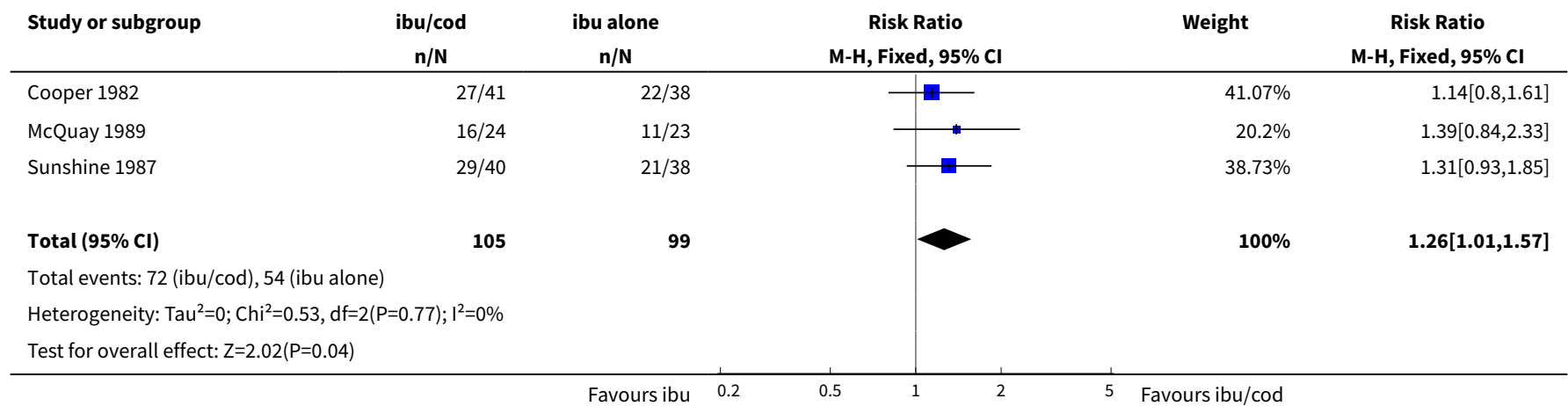

\section{APPENDICES}

\section{Appendix 1. Search strategy for MEDLINE (via Ovid)}

1. Ibuprofen/ or (ibuprofen or brufen or propionic acid or isobutylphenyl propionic acid).mp.

2. Codeine/ or codeine.mp.

3. 1 and 2

4. Pain, Postoperative/ 
5. ((postoperative adj4 pain $\left.{ }^{\star}\right)$ or (post-operative adj4 pain $\left.{ }^{\star}\right)$ or post-operative-pain ${ }^{\star}$ or (post* adj4 pain ${ }^{\star}$ ) or (postoperative adj4 analgesi ${ }^{\star}$ ) or (post-operative adj4 analgesi*) or "post-operative analgesi" $\left.{ }^{\star}\right) \cdot \mathrm{mp}$.

6. ((post-surgical adj4 pain^) or ("post surgical" adj4 pain*) or (post-surgery adj4 pain*)).mp.

7. ("pain-relief after surg*" or "pain following surg*" or "pain control after").mp.

8. (("post surg*" or post-surg*) and (pain* or discomfort)).mp.

9. ((pain* adj4 "after surg*") or (pain* adj4 "after operat*") or (pain* adj4 "follow* operat*") or (pain* adj4 "follow* surg*")).mp.

10.((analgesi* adj4 "after surg*") or (analgesi* adj4 "after operat") or (analgesi* adj4 "follow* operat*") or (analgesi* adj4 "follow* surg*")).mp.

11.exp Surgical Procedures, Operative/

12.or/4-11

13.3 and 12

14. randomized controlled trial.pt.

15.controlled clinical trial.pt.

16.randomized.ab.

17. placebo.ab.

18.drug therapy.fs.

19.randomly.ab.

20.trial.ab.

21.groups.ab.

22.14 or 15 or 16 or 17 or 18 or 19 or 20 or 21

23.exp animals/ not humans.sh.

24.22 not 23

25.13 and 24

\section{Appendix 2. Search strategy for EMBASE (via Ovid)}

1. Ibuprofen/ or (ibuprofen or brufen or propionic acid or isobutylphenyl propionic acid).mp.

2. Codeine/ or codeine.mp.

3. 1 and 2

4. Pain, Postoperative/

5. ((postoperative adj4 pain $\left.{ }^{\star}\right)$ or (post-operative adj4 pain $\left.{ }^{\star}\right)$ or post-operative-pain* or (post* adj4 pain ${ }^{\star}$ ) or (postoperative adj4 analgesi ${ }^{\star}$ ) or (post-operative adj4 analgesi ${ }^{\star}$ ) or "post-operative analgesi $\left.{ }^{\star} "\right) . m p$.

6. ((post-surgical adj4 pain*) or ("post surgical" adj4 pain*) or (post-surgery adj4 pain*)).mp.

7. ("pain-relief after surg*" or "pain following surg*" or "pain control after").mp.

8. (("post surg*" or post-surg*) and (pain* or discomfort)).mp.

9. ((pain* adj4 "after surg*") or (pain* adj4 "after operat") or (pain* adj4 "follow* operat*") or (pain* adj4 "follow* surg*")).mp.

10. ((analgesi* adj4 "after surg*") or (analgesi* adj4 "after operat*") or (analgesi* adj4 "follow* operat" ${ }^{\star}$ ) or (analgesi* adj4 "follow" surg*")).mp.

11.exp Surgical Procedures, Operative/

12. or/4-11

13.3 and 12

14.random*.tw.

15.factorial ${ }^{*}$. tw.

16. crossover ${ }^{*}$.tw.

17.cross over ${ }^{\star}$. tw.

18.cross-over ${ }^{\star}$.tw.

19. placebo*.tw.

20. $\left(\right.$ doubl $^{\star}$ adj blind $\left.{ }^{\star}\right)$. tw.

21.(singl* adj blind $\left.^{\star}\right)$.tw.

22.assign ${ }^{\star}$. tw.

23. allocat ${ }^{\star}$.tw.

24. volunteer ${ }^{\star}$.tw. 
25. Crossover Procedure/

26.double-blind procedure.tw.

27. Randomized Controlled Trial/

28.Single Blind Procedure/

29.or/14-28

30.13 and 29

\section{Appendix 3. Search strategy for CENTRAL}

1. MeSH descriptor: [lbuprofen] this term only

2. (ibuprofen or brufen or propionic acid or "isobutylphenyl propionic acid")

3. MeSH descriptor: [Codeine] this term only

4. Codeine

5. 1 or 2

6. 3 or 4

7. 5 and 6

8. MeSH descriptor: [Pain, Postoperative] this term only

9. ((postoperative near/4 pain ${ }^{\star}$ ) or (post-operative near/4 pain $\left.{ }^{\star}\right)$ or (post-operative-pain ${ }^{\star}$ ) or (post ${ }^{\star}$ near/4 pain $\left.{ }^{\star}\right)$ or (postoperative near/4 analgesi $\left.{ }^{\star}\right)$ or (post-operative near/4 analgesi*) or ("post-operative analgesi*"))

10.((post-surgical near/4 pain*) or ("post surgical" near/4 pain $\left.{ }^{\star}\right)$ or (post-surgery near/4 pain $\left.\left.{ }^{\star}\right)\right)$

11.("pain-relief after surg*" or "pain following surg*" or "pain control after")

12.(("post surg*" or post-surg*) and (pain* or discomfort))

13. ((pain* near/4 "after surg*") or (pain* near/4 "after operat*") or (pain* near/4 "follow* operat*") or (pain* near/4 "follow* surg*"))

14. ((analgesi* near/4 "after surg*") or (analgesi ${ }^{\star}$ near/4 "after operat*") or (analgesi* near/4 "follow* operat*") or (analgesi ${ }^{\star}$ near/4 "follow* surg*"))

15.MeSH descriptor: [Surgical Procedures, Operative] explode all trees

16.8 or 9 or 10 or 11 or 12 or 13 or 14 or 15

17.7 and 16

\section{Appendix 4. Glossary}

Categorical rating scale: The most common is the five category scale (none, slight, moderate, good or lots, and complete). For analysis numbers are given to the verbal categories (for pain intensity, none $=0$, mild $=1$, moderate $=2$ and severe $=3$, and for relief none $=0$, slight $=1$, moderate $=2$, good or lots $=3$ and complete $=4$ ). Data from different subjects are then combined to produce means (rarely medians) and measures of dispersion (usually standard errors of means). The validity of converting categories into numerical scores was checked by comparison with concurrent visual analogue scale measurements. Good correlation was found, especially between pain relief scales using cross-modality matching techniques. Results are usually reported as continuous data, mean or median pain relief or intensity. Few studies present results as discrete data, giving the number of participants who report a certain level of pain intensity or relief at any given assessment point. The main advantages of the categorical scales are that they are quick and simple. The small number of descriptors may force the scorer to choose a particular category when none describes the pain satisfactorily.

Visual analogue scale (VAS): For pain intensity, lines with left end labelled "no pain" and right end labelled "worst pain imaginable", and for pain relief lines with left end labelled "no relief of pain" and right end labelled "complete relief of pain", seem to overcome the limitation of forcing patient descriptors into particular categories. Patients mark the line at the point which corresponds to their pain or pain relief. The scores are obtained by measuring the distance between the no relief end and the patient's mark, usually in millimetres. The main advantages of VAS are that they are simple and quick to score, avoid imprecise descriptive terms and provide many points from which to choose. More concentration and coordination are needed, which can be difficult post-operatively or with neurological disorders.

Total pain relief (TOTPAR) is calculated as the sum of pain relief scores over a period of time. If a patient had complete pain relief immediately after taking an analgesic, and maintained that level of pain relief for six hours, they would have a six-hour TOTPAR of the maximum of 24. Differences between pain relief values at the start and end of a measurement period are dealt with by the trapezoidal rule. This is a simple method that approximately calculates the definite integral of the area under the pain relief curve by calculating the sum of the areas of several trapezoids that together closely approximate to the area under the curve.

Summed pain intensity difference (SPID) is calculated as the sum of the differences between the pain scores and baseline pain score over a period of time. Differences between pain intensity values at the start and end of a measurement period are dealt with using the trapezoidal rule.

VAS TOTPAR and VAS SPID are visual analogue versions of TOTPAR and SPID. 
See "Measuring pain" in Bandolier's Little Book of Pain (Moore 2003).

Appendix 5. Summary of outcomes: analgesia and use of rescue medication

\begin{tabular}{|c|c|c|c|c|c|}
\hline \multirow[b]{2}{*}{ Study ID } & \multirow[b]{2}{*}{ Treatment } & \multicolumn{2}{|l|}{ Analgesia } & \multicolumn{2}{|c|}{ Rescue medication } \\
\hline & & PI or PR & $\begin{array}{l}\text { Number with } \\
\geq \mathbf{5 0 \%} \text { PR }\end{array}$ & $\begin{array}{l}\text { Median time } \\
\text { to use (h) }\end{array}$ & $\%$ using \\
\hline Cooper 1982 & $\begin{array}{l}\text { (1) Ibuprofen } 400 \mathrm{mg}+\text { codeine } 60 \mathrm{mg}, \mathrm{n}= \\
41 \\
\text { (2) Ibuprofen } 400 \mathrm{mg}, \mathrm{n}=38 \\
\text { (3) Aspirin } 650 \mathrm{mg}+\text { codeine } 60 \mathrm{mg}, \mathrm{n}=45 \\
\text { (4) Aspirin } 650 \mathrm{mg}, \mathrm{n}=38 \\
\text { (5) Codeine sulphate } 60 \mathrm{mg}, \mathrm{n}=41 \\
\text { (6) Placebo, } \mathrm{n}=46\end{array}$ & $\begin{array}{l}\text { TOTPAR 4: } \\
\text { (1) } 9.39 \\
\text { (2) } 8.39 \\
\text { (3) } 7.89 \\
\text { (4) } 5.66 \\
\text { (5) } 4.12 \\
\text { (6) } 2.65\end{array}$ & $\begin{array}{l}\text { (1) } 27 / 41 \\
\text { (2) } 22 / 38 \\
\text { (5) } 9 / 41 \\
\text { (6) } 5 / 46\end{array}$ & $\begin{array}{l}\text { Mean: } \\
\text { (1) } 3.66 \\
\text { (2) } 3.76 \\
\text { (3) } 3.56 \\
\text { (4) } 2.97 \\
\text { (5) } 2.64 \\
\text { (6) } 2.39\end{array}$ & No data \\
\hline Daniels 2011 & $\begin{array}{l}\text { (1) Ibuprofen } 400 \mathrm{mg}+\text { codeine } 25.6 \mathrm{mg}, \mathrm{n} \\
=169 \\
\text { (2) Paracetamol } 1000 \mathrm{mg}+\text { codeine } 30 \mathrm{mg} \text {, } \\
\mathrm{n}=113 \\
\text { (3) Ibuprofen } 200 \mathrm{mg}+\text { paracetamol } 500 \\
\mathrm{mg}, \mathrm{n}=173 \\
\text { (4) Ibuprofen } 400 \mathrm{mg}+\text { paracetamol } 1000 \\
\mathrm{mg}, \mathrm{n}=168 \\
\text { (5) Placebo, } \mathrm{n}=55\end{array}$ & $\begin{array}{l}\text { TOTPAR 6: } \\
\text { (1) } 13.38 \\
\text { (2) } 11.22 \\
\text { (3) } 14.16 \\
\text { (4) } 15.48 \\
\text { (5) } 2.64\end{array}$ & $\begin{array}{l}\text { (1) } 106 / 169 \\
\text { (5) } 2 / 55\end{array}$ & $\begin{array}{l}\text { (1) } 8.05 \\
\text { (2) } 5.78 \\
\text { (3) } 8.18 \\
\text { (4) } 9.95 \\
\text { (5) } 1.68\end{array}$ & $\begin{array}{l}\text { No useable } \\
\text { data }\end{array}$ \\
\hline Frame 1986 & $\begin{array}{l}\text { (1) Ibuprofen } 200 \mathrm{mg}+\text { codeine } 15 \mathrm{mg}, \mathrm{n}= \\
32 \\
\text { (2) Ibuprofen } 400 \mathrm{mg}+\text { codeine } 30 \mathrm{mg}, \mathrm{n}= \\
26 \\
\text { (3) Ibuprofen } 800 \mathrm{mg}+\text { codeine } 60 \mathrm{mg}, \mathrm{n}= \\
26 \\
\text { (4) Aspirin } 600 \mathrm{mg}, \mathrm{n}=25 \\
\text { (5) Placebo, } \mathrm{n}=26\end{array}$ & $\begin{array}{l}\text { TOTPAR 5: } \\
\text { (1) } 10.22 \\
\text { (2) } 11.22 \\
\text { (3) } 12.11 \\
\text { (4) } 10.06 \\
\text { (5) } 7.42\end{array}$ & $\begin{array}{l}\text { (1) } 18 / 32 \\
\text { (2) } 16 / 26 \\
\text { (3) } 18 / 26 \\
\text { (5) } 10 / 26\end{array}$ & $\begin{array}{l}\text { (1) } n / a \\
\text { (2) } n / a \\
\text { (3) } n / a \\
\text { (4) } 2.7 \\
\text { (5) } 3.0\end{array}$ & $\begin{array}{l}\text { (1) } 10 / 32 \\
\text { (2) } 7 / 26 \\
\text { (3) } 4 / 26 \\
\text { (4) } 21 / 33 \\
\text { (5) } 20 / 26\end{array}$ \\
\hline McQuay 1989 & $\begin{array}{l}\text { (1) Ibuprofen } 400 \mathrm{mg}+\text { codeine } 20 \mathrm{mg}, \mathrm{n}= \\
24 \\
\text { (2) Ibuprofen } 400 \mathrm{mg}, \mathrm{n}=23\end{array}$ & $\begin{array}{l}\text { TOTPAR 6: } \\
\text { (1) } 13.9 \\
\text { (2) } 10.8\end{array}$ & $\begin{array}{l}\text { (1) } 16 / 24 \\
\text { (2) } 11 / 23\end{array}$ & No data & $\begin{array}{l}\text { No useable } \\
\text { data }\end{array}$ \\
\hline Petersen 1993 & $\begin{array}{l}\text { (1) Ibuprofen } 400 \mathrm{mg}+\text { codeine } 60 \mathrm{mg}, \mathrm{n}= \\
29 \\
\text { (2) Ibuprofen } 400 \mathrm{mg}, \mathrm{n}=31\end{array}$ & No usable data & No data & No data & No data \\
\hline Sunshine 1987 & $\begin{array}{l}\text { (1) Ibuprofen } 200 \mathrm{mg}+\text { codeine } 30 \mathrm{mg}, \mathrm{n}= \\
40 \\
\text { (2) Ibuprofen } 400 \mathrm{mg}+\text { codeine } 60 \mathrm{mg}, \mathrm{n}= \\
40 \\
\text { (3) Ibuprofen } 400 \mathrm{mg}, \mathrm{n}=38 \\
\text { (4) Codeine sulphate } 60 \mathrm{mg}, \mathrm{n}=37 \\
\text { (5) Placebo, } \mathrm{n}=40\end{array}$ & $\begin{array}{l}\text { TOTPAR 4: } \\
\text { (1) } 8.41 \\
\text { (2) } 10.23 \\
\text { (3) } 8.09 \\
\text { (4) } 7.04 \\
\text { (5) } 5.21\end{array}$ & $\begin{array}{l}\text { (1) } 23 / 40 \\
\text { (2) } 29 / 40 \\
\text { (3) } 21 / 38 \\
\text { (4) } 17 / 37 \\
\text { (5) } 13 / 40\end{array}$ & $\begin{array}{l}\text { No useable } \\
\text { data }\end{array}$ & $\begin{array}{l}\text { At } 4 \mathrm{~h} \\
\text { (1) } 6 / 40 \\
\text { (2) } 2 / 40 \\
\text { (3) } 4 / 38 \\
\text { (4) } 8 / 37 \\
\text { (5) } 20 / 40\end{array}$ \\
\hline
\end{tabular}

Appendix 6. Summary of outcomes: adverse events and withdrawals 


\section{Adverse events}

\begin{tabular}{|c|c|c|c|c|}
\hline Study ID & Treatment & Any & Serious & Withdrawals \\
\hline Cooper 1982 & $\begin{array}{l}\text { (1) Ibuprofen } 400 \mathrm{mg}+\text { codeine } 60 \mathrm{mg}, \mathrm{n} \\
=41 \\
\text { (2) Ibuprofen } 400 \mathrm{mg}, \mathrm{n}=38 \\
\text { (3) Aspirin } 650 \mathrm{mg}+\text { codeine } 60 \mathrm{mg}, \mathrm{n}= \\
45 \\
\text { (4) Aspirin } 650 \mathrm{mg}, \mathrm{n}=38 \\
\text { (5) Codeine sulphate } 60 \mathrm{mg}, \mathrm{n}=41 \\
\text { (6) Placebo, } \mathrm{n}=46\end{array}$ & $\begin{array}{l}\text { (1) } 18 / 41 \\
\text { (2) } 11 / 38 \\
\text { (5) } 11 / 38 \\
\text { (6) } 5 / 46 \\
\text { Events were mostly drowsi- } \\
\text { ness and nausea }\end{array}$ & None & None \\
\hline Daniels 2011 & $\begin{array}{l}\text { (1) Ibuprofen } 400 \mathrm{mg}+\text { codeine } 25.6 \mathrm{mg} \text {, } \\
\mathrm{n}=169 \\
\text { (2) Paracetamol } 1000 \mathrm{mg}+\text { codeine } 30 \\
\mathrm{mg}, \mathrm{n}=113 \\
\text { (3) Ibuprofen } 200 \mathrm{mg}+\text { paracetamol } 500 \\
\mathrm{mg}, \mathrm{n}=173 \\
\text { (4) Ibuprofen } 400 \mathrm{mg}+\text { paracetamol } \\
\text { 1000 mg, } n=168 \\
\text { (5) Placebo, } n=55\end{array}$ & $\begin{array}{l}\text { (1) } 59 / 169 \\
\text { (5) } 21 / 55 \\
\text { Events were nausea, vom- } \\
\text { iting, headache, dizziness, } \\
\text { alveolar osteitis, body tem- } \\
\text { perature increased }\end{array}$ & None & None \\
\hline Frame 1986 & $\begin{array}{l}\text { (1) Ibuprofen } 200 \mathrm{mg}+\text { codeine } 15 \mathrm{mg}, \mathrm{n} \\
=32 \\
\text { (2) Ibuprofen } 400 \mathrm{mg}+\text { codeine } 30 \mathrm{mg}, \mathrm{n} \\
=26 \\
\text { (3) Ibuprofen } 800 \mathrm{mg}+\text { codeine } 60 \mathrm{mg}, \mathrm{n} \\
=26 \\
\text { (4) Aspirin } 600 \mathrm{mg}, \mathrm{n}=25 \\
\text { (5) Placebo, } \mathrm{n}=26\end{array}$ & $\begin{array}{l}\text { (1) } 2 / 32 \\
\text { (2) } 0 / 26 \\
\text { (3) } 9 / 26 \\
\text { (4) } 3 / 33 \\
\text { (5) } 5 / 26 \\
\text { Events were nausea, dys- } \\
\text { pepsia, tiredness, faint- } \\
\text { ness/shakiness, headaches, } \\
\text { photophobia, muscle ache, } \\
\text { and sore mouth }\end{array}$ & None & None \\
\hline McQuay 1989 & $\begin{array}{l}\text { (1) Ibuprofen } 400 \mathrm{mg}+\text { codeine } 20 \mathrm{mg}, \mathrm{n} \\
=24 \\
\text { (2) Ibuprofen } 400 \mathrm{mg}, \mathrm{n}=23\end{array}$ & $\begin{array}{l}\text { No single dose data } \\
\text { After } 2 \text { days, multiple doses } \\
\text { (1) } 3 / 24 \\
\text { (2) } 5 / 23\end{array}$ & None & None \\
\hline Petersen 1993 & $\begin{array}{l}\text { (1) Ibuprofen } 400 \mathrm{mg}+\text { codeine } 60 \mathrm{mg}, \mathrm{n} \\
=29 \\
\text { (2) Ibuprofen } 400 \mathrm{mg}, \mathrm{n}=31\end{array}$ & $\begin{array}{l}\text { No single dose data } \\
\text { After } 2 \text { doses } \\
\text { (1) } 14 / 29 \\
\text { (2) } 6 / 31\end{array}$ & None & None \\
\hline Sunshine 1987 & $\begin{array}{l}\text { (1) Ibuprofen } 200 \mathrm{mg}+\text { codeine } 30 \mathrm{mg}, \mathrm{n} \\
=40 \\
\text { (2) Ibuprofen } 400 \mathrm{mg}+\text { codeine } 60 \mathrm{mg}, \mathrm{n} \\
=40 \\
\text { (3) Ibuprofen } 400 \mathrm{mg}, \mathrm{n}=38 \\
\text { (4) Codeine sulphate } 60 \mathrm{mg}, \mathrm{n}=37 \\
\text { (5) Placebo, } \mathrm{n}=40\end{array}$ & $\begin{array}{l}\text { (1) } 1 / 40 \\
\text { (2) } 1 / 40 \\
\text { (3) } 0 / 38 \\
\text { (4) } 0 / 37 \\
\text { (5) } 0 / 40 \\
\text { Events were drowsiness } \\
\text { (moderate) and numbness } \\
\text { of legs (mild) }\end{array}$ & None & None \\
\hline
\end{tabular}


WHAT'S NEW

\begin{tabular}{lll}
\hline Date & Event & Description \\
\hline 29 May 2019 & Amended & Contact details updated. \\
\hline 14 November 2016 & Review declared as stable & See Published notes. \\
\hline
\end{tabular}

\section{H I S T O R Y}

Protocol first published: Issue 9, 2012

Review first published: Issue 3, 2013

\begin{tabular}{lll}
\hline Date & Event & Description \\
\hline 1 December 2014 & $\begin{array}{l}\text { New citation required but conclusions } \\
\text { have not changed }\end{array}$ & No new studies. Results not changed \\
\hline 1 December 2014 & New search has been performed & $\begin{array}{l}\text { New searches run on 1 December 2014; no new studies iden- } \\
\text { tified. 'Summary of findings' table added and minor changes } \\
\text { made to wording of 'Plain language summary'. Correction to } \\
\text { wording in analysis of ibuprofen plus codeine versus same dose } \\
\text { of ibuprofen alone }\end{array}$ \\
\hline
\end{tabular}

\section{CONTRIBUTIONSOF AUTHORS}

All authors contributed to writing the protocol.

For the original review, SMK and SD carried out searches, assessed studies for inclusion, and extracted data. RAM acted as arbitrator. All authors were involved in writing the review.

For the update RAM and SD carried out searches and revised the text where necessary. All authors read the final review.

RAM will be responsible for updating the review.

\section{DECLARATIONSOF INTEREST}

RAM and SD have received research support from charities, government and industry sources at various times, but none related to this review. RAM has consulted for various pharmaceutical companies and has received lecture fees from pharmaceutical companies related to analgesics and other healthcare interventions. SK has no interests to declare.

\section{SOURCES OF SUPPORT}

\section{Internal sources}

- Oxford Pain Relief Trust, UK.

\section{External sources}

- No sources of support supplied

\section{DIFFERENCES BETWEEN PROTOCOL AND REVIEW}

We have included additional information relating to the criteria used to assess risk of bias in this updated review. 


\section{NOTES}

A new search is not likely to identify any potentially relevant studies likely to change the conclusions and this review has been stabilised following discussion with the authors and editors. If appropriate, we will update the review if new evidence likely to change the conclusions is published, or if standards change substantially which necessitate major revisions.

\section{N DEX TERMS}

\section{Medical Subject Headings (MeSH)}

Acute Pain [ ${ }^{*}$ drug therapy]; Analgesics, Opioid [ ${ }^{*}$ administration \& dosage]; Codeine [ ${ }^{*}$ administration \& dosage]; Drug Combinations; Ibuprofen [ ${ }^{\star}$ administration \& dosage]; Pain, Postoperative [ ${ }^{*}$ drug therapy]; Randomized Controlled Trials as Topic; Treatment Outcome

\section{MeSH check words}

Adult; Humans 